\title{
Bacterial endophthalmitis in the age of outpatient intravitreal therapies and cataract surgeries: Host-microbe interactions in intraocular infection
}

\section{Citation}

Sadaka, Ama, Marlene L. Durand, and Michael S. Gilmore. 2012. Bacterial Endophthalmitis in the Age of Outpatient Intravitreal Therapies and Cataract Surgeries: Host-microbe Interactions in Intraocular Infection. Progress in Retinal and Eye Research 31: 316-331. doi:10.1016/ j.preteyeres.2012.03.004.

\section{Published Version}

doi:10.1016/j.preteyeres.2012.03.004

\section{Permanent link}

http://nrs.harvard.edu/urn-3:HUL.InstRepos:33867381

\section{Terms of Use}

This article was downloaded from Harvard University's DASH repository, and is made available under the terms and conditions applicable to Other Posted Material, as set forth at http:// nrs.harvard.edu/urn-3:HUL.InstRepos:dash.current.terms-of-use\#LAA

\section{Share Your Story}

The Harvard community has made this article openly available.

Please share how this access benefits you. Submit a story.

Accessibility 


\title{
Bacterial endophthalmitis in the age of outpatient intravitreal therapies and cataract surgeries: Host-microbe interactions in intraocular infection
}

\author{
Ama Sadaka, MD ${ }^{1,2}$, Marlene L Durand, MD $^{3}$, and Michael S Gilmore, PhD $^{1,2,4}$ \\ ${ }^{1}$ Department of Ophthalmology, Harvard Medical School, Boston, USA \\ ${ }^{2}$ Department of Ophthalmology, Massachusetts Eye and Ear Infirmary, Boston, USA \\ ${ }^{3}$ Division of Infectious Diseases, Department of Medicine, Massachusetts General Hospital, \\ Boston, MA, USA \\ ${ }^{4}$ Department of Microbiology and Molecular Genetics, Harvard Medical School, Boston, MA, USA
}

\section{Abstract}

Bacterial endophthalmitis is a sight threatening infection of the interior structures of the eye. Incidence in the US has increased in recent years, which appears to be related to procedures being performed on an aging population. The advent of outpatient intravitreal therapy for management of age-related macular degeneration raises yet additional risks. Compounding the problem is the continuing progression of antibiotic resistance. Visual prognosis for endophthalmitis depends on the virulence of the causative organism, the severity of intraocular inflammation, and the timeliness of effective therapy. We review the current understanding of the pathogenesis of bacterial endophthalmitis, highlighting opportunities for the development of improved therapeutics and preventive strategies.

\section{Keywords}

Endophthalmitis; Staphylococcus aureus; coagulase-negative staphylococci; Streptococcus pneumoniae; Enterococcus faecalis; Bacillus

\begin{abstract}
Bacterial endophthalmitis is a sight threatening intraocular infection. Endophthalmitis may arise exogenously or endogenously. In exogenous bacterial endophthalmitis, bacteria enter the eye through a breach in the globe, such as surgery, intraocular injection, penetrating trauma, or intraocular extension of infection of the cornea (keratitis) or a glaucoma filtering bleb (blebitis). Endogenous bacterial endophthalmitis stems from bacteremic seeding of the eye; the source of bacteremia may be transient (e.g. from intravenous drug abuse) or persistent (e.g. endocarditis). In this paper, we review the current understanding of the pathogenesis of bacterial endophthalmitis to aid the ultimate goal of developing better therapeutic and preventive strategies.
\end{abstract}

(C) 2012 Elsevier Ltd. All rights reserved.

Corresponding author: Michael S. Gilmore, 243 Charles Street, Boston, MA 02114, michael_gilmore@ meei.harvard.edu.

Publisher's Disclaimer: This is a PDF file of an unedited manuscript that has been accepted for publication. As a service to our customers we are providing this early version of the manuscript. The manuscript will undergo copyediting, typesetting, and review of the resulting proof before it is published in its final citable form. Please note that during the production process errors may be discovered which could affect the content, and all legal disclaimers that apply to the journal pertain. 


\section{The problem of endophthalmitis}

The rate of intraocular procedures is increasing, especially cataract removal and lens replacement, now one of the most commonly performed surgeries in the developed world (Brian and Taylor 2001). There has also been a marked increase in the number of intravitreal injections for treatment of neovascular eye disease and intraocular inflammation (Peyman et al. 2009). This has been accompanied by a commensurate increase in the number of injection-related complications. The incidence of endophthalmitis after intravitreal injection ranges from $0.006 \%$ to $0.16 \%$ per injection, or between $0.07 \%$ and $1.3 \%$ per patient treatment period (Diago et al. 2009, Klein et al. 2009, Sampat and Garg 2010, VEGF Inhibition Study in Ocular Neovascularization (V.I.S.I.O.N.) Clinical Trial Group et al. 2006). Endophthalmitis is the leading infectious complication of cataract surgery, with an incidence of $0.01 \%$ to $0.3 \%$ (Endophthalmitis Study Group, European Society of Cataract \& Refractive Surgeons 2007, Taban et al. 2005) and the rate has increased in recent years (West et al. 2005). Infection also often follows traumatic injury to the globe, with an incidence of posttraumatic bacterial endophthalmitis ranging from $0.9 \%$ to $17 \%$ (Jonas et al. 2000, Thompson et al. 1993, Thompson et al. 1995).

Complicating the rise in endophthalmitis, antibiotic resistance is increasing among common causes of endophthalmitis, resulting in more resistance-related treatment failure (JuarezVerdayes et al. 2006, Major et al. 2010, Tang et al. 2007). Methicillin resistant Staphylococcus aureus (MRSA) endophthalmitis represents approximately $40 \%$ of $S$. aureus endophthalmitis cases in some centers (Deramo et al. 2008, Major et al. 2010). Intermediate vancomycin resistance has been reported in staphylococcal infections of the eye (JuarezVerdayes et al. 2006), and full vancomycin resistance in enterococci is common (Tang et al. 2007). Recently, full vancomycin resistance has transferred from the enterococci to $S$. aureus (Centers for Disease Control and Prevention (CDC) 2002, Finks et al. 2009), but these strains have yet to cause eye infection. Resistance to newer fluoroquinolones is also on the rise (Deramo et al. 2008, Miller et al. 2006).

Visual prognosis after bacterial infection depends greatly on 1) the virulence of the causative organism, 2) visual acuity at presentation, and 3) efficacy of treatment (EVS 1996).

Although infection resolves well in about $2 / 3$ of cases using current intravitreal antibiotic regimens, and occasionally anti-inflammatory agents and vitrectomy, significant visual loss occurs in the remaining $1 / 3$ of cases. In an effort to prevent infection and improve outcome, considerable effort is being invested in understanding the pathogenesis of endophthalmitis, and identifying critical points in the process that represent opportunities for intervention.

The most common microbes isolated from cases of post-surgical endophthalmitis are coagulase-negative staphylococci, principally Staphylococcus epidermidis, and most of these infections resolve well (Lalwani et al. 2008, Miller et al. 2007). Staphylococcus aureus is the second most common cause of acute postoperative infection following cataract and glaucoma surgeries, and vitrectomy. Following traumatic injury, Bacillus cereus is a leading concern, in part because of the explosiveness of infection (Table 1). Bacillus, S. aureus, and streptococcal endophthalmitis are associated with significant visual loss (Lalwani et al. 2008, Major et al. 2010).

\section{The relationship between bacterial virulence and outcome: Progress toward an understanding}

The main concern in endophthalmitis is that in infection caused by virulent organisms, visual loss often results despite effective antimicrobial therapy. Improved therapeutic strategies may result from a better understanding of exactly what constitutes virulence in the 
host pathogen interaction. The pathophysiology of infection in the unique anatomical and immunological environment of the eye is beginning to be investigated. In other cases, we must extrapolate from experiments performed at other anatomical sites, and in vitro.

\subsection{Staphylococcus aureus}

2.1.1 S. aureus cell wall components-S. aureus is a gram-positive bacterium and leading cause of postoperative and posttraumatic endophthalmitis, often associated with vision loss (Kattan et al. 1991, Pijl et al. 2010, Shirodkar et al. 2010). Its pathogenicity for the eye is believed to stem from the variety of virulence traits that it expresses, and from the host response to its presence. $S$. aureus cell wall components, including peptidoglycan, lipoproteins and teichoic acids, play important roles in virulence by contributing to immunostimulation and immune evasion (Bera et al. 2007, Hashimoto et al. 2006). Lipoteichoic acid and peptidoglycan in the cell wall are each capable of activating complement causing the release of cytokines and chemokines by monocytes and macrophages (Howes et al. 1994, Timmerman et al. 1993). Recently, wall teichoic acids (WTA) have been studied to understand their role in $S$. aureus endophthalmitis (Suzuki et al. 2011). WTA, a major polyanionic polymer component of $S$. aureus cell wall, is essential for the manifestation of virulence in endophthalmitis, and has been targeted with small molecule inhibitors of its biosynthesis (Suzuki et al. 2011). Cell wall anchored protein A binds the Fc region of immunoglobulin G, coating the cell surface and preventing neutrophils from binding, thus interfering with phagocytosis (Cedergren et al. 1993, Patel et al. 1987). Protein A also appears to be employed by $S$. aureus to evade an antigen-specific B cell response (Bekeredjian-Ding et al. 2007). It was identified as a sensitizer of B cells for the recognition of TLR2-active lipopeptides promoting T-cell independent B cell proliferation, without inducing secretion of IgM (Bekeredjian-Ding et al. 2007). It also activates a specific clone of T cells (Sinha et al. 1999). Protein A has also been described to elicit release of IL-1 and increase production of TNF-a and nitric oxide in vivo through activation of macrophages (Singh et al. 1992, Sinha et al. 1999).

2.1.2 Quorum sensing system and biofilm formation-S. aureus exists in alternate physiologic states depending upon environmental conditions/stressors, and number of bacteria: Planktonic (free-living, mobile) and sessile (stationary, biofilm-forming) states correlate with changes in bacterial physiology and virulence expression. We are starting to understand the many regulatory mechanisms involved in the transition from planktonic to biofilm phenotypes.

At low cell density, $S$. aureus expresses cell surface proteins including protein A, coagulase and fibronectin binding proteins and other adhesins, that are thought to promote colonization and evasion of the immune system (Goerke and Wolz 2004, Novick 2003). This state of upregulation of adhesion molecules correlates also with the initiation of biofilm formation that is thought to allow bacteria to survive conditions hostile to single cell planktonic growth (Beveridge et al. 1997). At higher cell densities, gene expression shifts to production of secreted factors, such as hemolysins and proteases that are associated with tissue damage and tissue invasion (Dunman et al. 2001).

The accessory gene regulator ( $a g r)$ system is a main determinant of cell density-dependent regulation of gene expression by $S$. aureus (Fig. 1). The agr operon encodes an autoinducer peptide (AIP). Four AIP structural subgroups have been identified, each synthesized as a precursor and post translationally modified and processed to an8 amino acid cyclic peptide containing a conserved thiolactone ring (Jarraud et al. 2000, Ji et al. 1997). AIPs are species and strain specific, and exhibit cross interference such that one AIP can serve as an antagonist of another (Novick 2003, Otto et al. 1999). The agr system is transcribed in two 
RNAs, RNA II and RNA III. Each is divergently transcribed from promoters $\mathrm{P} 2$ and P3 respectively. RNA II encodes the four structural genes; $\operatorname{agr} A, B, C$ and $D$. agr $D$ encodes the precursor of the AIP that matures through proteolyticcleavage by a membrane anchored protein, $\operatorname{agr}_{r} B$, into the active form capable of binding the cell surface exposed domain of the trans-membrane sensor kinase, AgrC. This leads to the activation of the response regulator, AgrA, triggering increased transcription of RNA II and RNA III. RNA III, which is a regulatory RNA that also encodes delta toxin, regulates expression of other virulence factors. Its 5 ' end has been shown to positively regulate alpha toxin expression from the hla gene (Morfeldt et al. 1995), and its 3' end represses the synthesis of protein A (Huntzinger et al. 2005).

The Staphylococcal Accessory Regulator (SarA) protein family supplements agr in regulating expression of virulence genes. SarA is a DNA-binding protein that activates target genes by binding to a conserved A/T-rich recognition motif of select promoters. SarA promotes synthesis of fibronectin- and fibrinogen-binding proteins involved in adhesion of bacteria, and synthesis of $\alpha-, \beta$ - and $\delta$-toxins involved in tissue lysis and spread of infection (Chien et al. 1999, Dunman et al. 2001). Expression of SarA peaks during the late exponential phase and coincides with agr activation (Rechtin et al. 1999). SarA, is required for full agr regulation, as it influences expression of RNA III, the agr effector molecule. Several sarA homologs have been identified and their role in regulating gene expression is being studied. SarR, for instance, peaks during post-exponential phase and represses sar $A$ transcription during the late exponential and stationary phases (Manna and Cheung 2001). SarS, repressed by agr and sarA, activates transcription of spa encoding surface protein A and it represses the expression of the alpha toxin gene (Tegmark et al. 2000). SarT that is repressed by sarA and agr, represses alpha toxin expression (Schmidt et al. 2001), highlighting the complexity of virulence regulation in $S$. aureus.

Some work has been done to evaluate the role of agr and $\operatorname{sar} A$ in the pathogenesis of endophthalmitis. A sarA mutant, which exhibits decreased extracellular protein and cell surface protein expression but increased production of lipolytic and proteolytic proteins, shows surprisingly little change by itself in virulence in an endophthalmitis model compared to its wild type parent (Booth et al. 1997). Mutations in $a g r$, however are highly attenuated (Booth et al. 1995, Booth et al. 1997, Giese et al. 1999). The agr-deficient strain expresses decreased levels of alpha, beta, gamma and delta toxins, TSST-1 and staphylococcal enterotoxins $\mathrm{B}$ and $\mathrm{C}$, with increase in protein $\mathrm{A}$ and fibronectin-binding protein expression (Booth et al. 1995, Morfeldt et al. 1988). An agr/sar double mutant is almost completely attenuated (Booth et al. 1997). Evaluating the role of the individual cytolysins revealed that their contribution to the severity of endophthalmitis disease progression is complex and partly additive (Booth et al. 1995). Among the different toxins, a significant role for the alpha and beta toxins was identified. Infections with strains deficient in these toxins retained significantly more retinal function and showed less inflammation (Callegan et al. 2002b).

Alpha toxin is a well characterized pore-forming toxin that, in addition to its direct lytic effect, causes ATP and calcium ion leakage at sub-lytic levels, triggering the arachidonic acid cascade in endothelial cells and causing the inflammatory reaction (Walev et al. 1993). The beta toxin is a magnesium-dependent sphingomyelinase $\mathrm{C}$ that degrades sphingomyelin in the outer leaflet of erythrocytes, decreasing viability and eventually lysing monocytes and lymphocytes, with accompanying cytokine release (Huseby et al. 2007, Marshall et al. 2000). Culture fluids containing these toxins are highly inflammatory and toxic to the retina (Callegan et al. 1999a).

The Agr and the SarA regulators control staphylococcal gene expression under changing environmental conditions, including the transition from planktonic to biofilm growth. Generally, the transition from planktonic to biofilm growth (and back) requires cell 
attachment, proliferation, biofilm maturation and finally cell detachment. Loss of agr function leads to upregulation of surface features that facilitate attachment to polystyrene surfaces (Vuong et al. 2000) and increased propensity to form biofilms, whereas mutations in $\operatorname{sar} A$ result in reduction in the capacity for biofilm formation (Beenken et al. 2010). These findings are supported by time-lapse confocal microscopic examination, which shows that detachment of cells from a biofilm coincides with agr expression (Yarwood et al. 2004). Thus, Agr activation reduces biofilm formation and enhances cell detachment, which is believed to contribute to dissemination of the microbe following establishment of a nidus of infection (Kong et al. 2006). This inability of cells to detach in agr mutants results in thicker biofilms than those formed by the wild type parental strain (Vuong et al. 2000, Vuong et al. 2004). Regulation of biofilm formation by agr is not entirely straight forward, however. Alpha-toxin expression, which is positively regulated by agr, enigmatically contributes to biofilm formation under static and flow conditions (Caiazza and O'Toole 2003). In the final stages, detachment from the biofilm is thought to be mediated in part by the surfactant properties of $\delta$-hemolysin, encoded by the agr locus itself (Vuong et al. 2000).

The polysaccharide intercellular adhesion (PIA) that forms part of the extracellular biofilm matrix, is encoded by the ica $A D B C$ operon, that promotes biofilm formation (Cramton et al. 2001, Jefferson et al. 2004). Increased expression of $i c a A D B C$ is triggered by environmental stress factors. This polymeric matrix contributes a physical barrier to penetration of some antimicrobials (Xu et al. 2000) and appears to offer an environment whereby $S$. aureus can deactivate reactive oxygen species (ROS) produced by the immune system (De Beer et al. 1994). The biofilm matrix chemistry is complex and includes proteinaceous material, extracellular DNA and polysaccharides. Thus enzymes such as DNase, trypsin and proteinase $\mathrm{K}$, and other biofilm dispersing compounds may aid in the treatment of infections caused by the persistence of bacteria on abiotic surfaces (Boles and Horswill 2011). After intraocular lens (IOL) insertion, biofilm formation is of particular concern as it has the potential of promoting the survival of bacteria, and rendering them resistant to clearance.

2.1.3 The stress regulator, $\sigma^{\mathrm{B}}$-Another regulatory factor involved in the stress response is $\sigma^{\mathrm{B}}$. The $\sigma^{\mathrm{B}}$ regulon includes more than a 100 genes involved in stress response, cell envelope biosynthesis, intermediary metabolism, and other signaling pathways (Bischoff et al. 2004). Among $\sigma^{\mathrm{B}}$ regulated genes related to virulence are those that contribute to bacterial aggregation and protection against the type of oxidative stress that can result from PMN engulfment and exposure to antibiotics (Bischoff et al. 2004, De Lencastre et al. 1999, Gertz et al. 2000, Kullik et al. 1998). Based on microarray analysis of the transcriptional profile of different $S$. aureus strains and their respective isogenic $\sigma^{\mathrm{B}}$ mutants, $\sigma^{\mathrm{B}}$ appears to fine tune virulence factor production in response to changing environments (Bischoff et al. 2004). $\sigma^{\mathrm{B}}$ was found to upregulate expression of many adhesins, and repress exoprotein and toxin production, and is thus likely to be acting conversely to RNA III, the effector molecule of agr (Bischoff et al. 2004).

2.1.4 Nutritional environment and virulence-Recently, CodY has been found to connect $S$. aureus virulence to metabolic state (Sonenshein 2007), and similar regulators likely exist for most pathogens. CodY is a GTP-binding global regulator, first identified in Bacillus subtilis (Sonenshein 2005). In that host, it senses the nutritional environment and regulates catabolic enzyme biosynthesis, and production of competence factors for DNA uptake (Hendriksen et al. 2008). In S. aureus, CodY influences regulation of RNA II and RNA III expression in the agroperon, and as a result, affects expression of alpha-toxin and likely other toxins. It also regulates production of PIA (Majerczyk et al. 2008), in addition to its role in regulating capsule production (Majerczyk et al. 2010). In addition to an indirect role in regulating virulence gene expression through $\operatorname{ag} r, \operatorname{cod} Y$ also directly regulates numerous transcription units associated with amino acid biosynthesis, transport of 
macromolecules, and virulence (Majerczyk et al. 2010). CodY is responsive to GTP and branched chain amino acid (BCAA) concentration in the environment. Isoleucine is a major ligand for CodY, and when present above a critical threshold, causes CodY to repress transcription of target genes (Pohl et al. 2009). Based on studies in other organisms, such as $S$. pyogenes, it was suggested that the requirements for CodY activation may be satisfied in the bloodstream and other tissues, resulting in a CodY-induced lag in expression of virulence, perhaps in an effort to stably co-exist with the host (Camargo and Gilmore 2008). We are beginning to examine on the role $\operatorname{cod} Y$ plays in ocular infection, given the presence of BCAA in the aqueous humor. Promoting CodY repression of virulence in infection could open new therapeutic opportunities for limiting ocular damage, perhaps using only non-toxic amino acids administered or restricted at the site of infection.

2.1.5 S. aureus pathogenesis atextraocularsites-Much of what is known about the role of quorum sensing and nutritional variables has been determined in the context of infection at other anatomical sites. For $S$. aureus to survive in the blood, they first need to protect themselves from killing by neutrophils and to that end they employ factors like carotenoid staphyloxanthin (Pelz et al. 2005), which scavenges reactive oxygen species; phenol soluble modulins, which disrupt the plasma membrane integrity of neutrophils (Wang et al. 2007); and clumping factor (ClfA) that binds fibrinogen, triggering staphylococcal agglutination reducing the effectiveness of phagocytosis (Palmqvist et al. 2004). ClfA is also believed to enable staphylococci to adhere to fibrin on the vascular endothelium, contributing to vegetation formation and endocarditis pathogenesis (Moreillon et al. 1995). The chemotaxis inhibitory protein of $S$. aureus (CHIPS) acts as a specific and potent inhibitor of neutrophil anaphylatoxin $\mathrm{C} 5 \mathrm{a}$, which plays a crucial role in the early recruitment of neutrophils to the infection site (Postma et al. 2004). High levelC5a can be deleterious in inflammatory and autoimmune diseases, including rheumatoid arthritis, inflammatory bowel disease and reperfusion injury (Bunschoten et al. 2011). Specific inhibition of C5a activation through modification of CHIPS is considered a promising strategy to treat such conditions (Allegretti et al. 2005, Bunschoten et al. 2011).

In an abscess model, it was found that administration of an inhibitory auto-inducing peptide delayed agr activation for 2-4 hours only (Wright et al. 2005). However, this was sufficient to limit formation of the abscess, suggesting that agr expression is required early in infection (Wright et al. 2005). Abscess formation in the kidney was recently shown to be restricted by the host protein, calprotectin, which chelates divalent metals including $\mathrm{Mn}^{+2}$ and $\mathrm{Zn}^{+2}$ (Corbin et al. 2008). Specifically, restriction of $\mathrm{Mn}^{+2}$ was shown to be the critical factor in limiting $S$. aureus abscess formation. Furthermore, $S$. aureus surface protein A, and coagulation factors like coagulase (Coa) and von Willebrand factor-binding protein (vWbp), are essential for abscess formation (Cheng et al. 2011). Questions that are unresolved with respect to the pathogenesis of $S$. aureus endophthalmitis include: Why does $S$. aureus make such a plethora of exotoxins? Do most of these induce subtle changes in host cell behavior at sub-toxic levels during asymptomatic colonization and carriage? To what extent does immune privilege alter the course of infection or abscess formation - particularly with respect to factors, such as CHIPS and Eap that target immune cells? How exactly does $S$. aureus damage the retina? Does it need to translocate from the anterior chamber to the vitreous when the posterior capsule is intact, or are the toxins produced along with the inflammation mounted by the host sufficient to cause the damage?

\subsection{Coagulase-negative staphylococci (CoNS)}

Coagulase-negative staphylococci (CoNS) are primary colonizers of the keratinized and wet epithelium of humans, but can cause infection when introduced into a sterile site. As a result of this proximity, they are leading causes of medical implant and device-related infections. 
The increased uses of medical devices, along with the spread of antibiotic resistance, have heightened interest in better understanding this microbe in the context of infection (Raad et al. 1998). In the eye, CoNS, mainly $S$. epidermidis (although it is often not identified to the species level), are the most common causes of postoperative endophthalmitis, accounting for $70 \%$ of cases following cataract extraction. Most cases resolve well with treatment, with little visual loss. The rise in methicillin and fluoroquinolone resistance, as well as reduced glycopeptide susceptibility in S. epidermidis, is of concern (Giacometti et al. 2000, Raad et al. 1998, Villari et al. 2000).

2.2.1 Virulence in S. epidermidis_ $S$. epidermidis possesses gene regulatory mechanisms that are similar to $S$. aureus, including an agr quorum sensing system. However, $S$. epidermidis lacks many of the toxins expressed by $S$. aureus. Its ability to form biofilms is important in the pathogenesis of infection, likely including endophthalmitis (Bainbridge et al. 1998, Garzozi and Harris 2000). Biofilm production by $S$. epidermidis involves synthesis and secretion of a $\beta$-1,6-linked $\mathrm{N}$-acetylglucosamine polysaccharide intercellular adhesion (PIA) similar to that expressed by $S$. aureus. Biofilm formation involves adhesive surface proteins, such as ClfA (Heilmann et al. 1997) mediating bacterial binding to fibrinogen, and the AtlE autolysin and Spp1 holin (Gotz 2002) which release bacterial DNA into the biofilm, in addition to PIA biosynthesis (Gotz 2002, Heilmann et al. 1997). The type of IOL used affects the extent of bacterial binding, with the greatest binding being observed to hydrophilic acrylic polymer, followed by poly-(methyl methacrylate), hydrophobic acrylic, and then silicone (Baillif et al. 2008).

S. epidermidis, like $S$. aureus, expresses several surface proteins, termed MSCRAMMs (microbial surface components recognizing adhesive matrix molecules), that bind matrix proteins of basement membranes and provisional wound matrix. SdrG, a fibrinogen-binding protein, has been found to be important for adhesion and central venous catheter-associated infection (Guo et al. 2007, Hartford et al. 2001, Nilsson et al. 1998). Besides binding to prosthetic devices and wounds, $S$. epidermidis like $S$. aureus, produces short hydrophobic peptides termed phenol soluble modulins, that appear to function as proinflammatory agents and thus contribute to tissue damage and host evasion (Otto 2009). Despite the incidence of $S$. epidermidis as a causative agent of endophthalmitis, few studies have examined virulence in the context of the eye.

\subsubsection{Methicillin resistance in staphylococci poses a serious challenge to} treatment-Following the introduction of methicillin in 1960, antibiotic resistance emerged quickly (Jevons et al. 1963). Methicillin resistant $S$. aureus (MRSA) are now leading causes of invasive infection and death in the US (Klevens et al. 2007). First being confined to the hospital environment, MRSA emerged in the community in the US in the mid 90's, causing infection in children and others with no prior healthcare contact (Zetola et al. 2005). Community associated MRSA (CA-MRSA) appear to be more virulent than hospital associated (HA-MRSA) strains (Kazakova et al. 2005, Tenover et al. 2006). A main distinguishing feature of community associated strains is the presence of a mobile genetic element that encodes an arginine catabolic mobile element (ACME) (Diep et al. 2006). This mobile element, located adjacent to the methicillin resistance determinant, is thought to have been horizontally transferred to $S$. aureus from $S$. epidermidis, and to confer enhanced skin colonization (Miragaia et al. 2009).

Methicillin is a beta-lactam antibiotic that inhibits bacterial cell wall synthesis by binding and inhibiting the activities of penicillin binding proteins (PBPs) on the cell wall. PBPs catalyze transpeptidation of the cell wall, creating essential peptidoglycan crosslinks. Methicillin resistance in staphylococci is conferred by the product of the mec $A$ gene, which encodes an unusual auxiliary penicillin binding protein, $\mathrm{PBP} 2 \mathrm{~A}$, that fails to bind 
methicillin, and thus renders methicillin and other structurally related $\beta$-lactam antibiotics incapable of blocking cell wall biosynthesis (Chambers 1997). In both $S$. aureus and $S$. epidermidis, mec $A$ occurs on the staphylococcal cassette chromosome mec (SCC mec) element (Katayama et al. 2000). There are 8 organizational classes of SCC mec among CoNS and $S$. aureus (Zhang et al. 2009). CoNS positive for $m e c A$ are believed to serve as a reservoir for methicillin-resistance determinants (Barbier et al. 2010, Garza-Gonzalez et al. 2010). Strains carrying SCC mec tend to be resistant to multiple antibiotics (Diep et al. 2006, Holden et al. 2004).

MRSA has been isolated from ocular infections, including endophthalmitis, bleb-associated infection, trauma associated infection, and endogenous endophthalmitis (Fukuda et al. 2002, Major et al. 2010, Pierre and Tang 2010). Resistance of staphylococcal ocular pathogens to penicillin and methicillin is as high as $42.9 \%$ in recent reports (Cavuoto et al. 2008, Haas et al. 2011). MRSA strains arealso becoming resistant to even advanced fluoroquinolones used in prophylaxis and treatment of ocular infections (Major et al. 2010). Data from the Tracking Resistance in the United States Today (TRUST) study of ocular isolates, the Surveillance Network for ocular S. aureus isolates, and the Antibiotic Resistance Monitoring in Ocular MicRorganisms (ARMOR) study, all show continued erosion in beta-lactam susceptibility among CoNS and $S$. aureus (Asbell et al. 2008a, Asbell et al. 2008b, Haas et al. 2011). Staphylococci have proven particularly adept at acquiring resistance to every antibiotic that has been introduced, including vancomycin, highlighting the importance of the judicious use of antibiotics.

\subsection{Enterococcus faecalis}

E. faecalis is mainly a commensal organism of the gastrointestinal tract, but it has emerged as a leading cause of hospital acquired and postoperative infections that are especially difficult to treat, in part because of the high level of intrinsic antibiotic resistance (Murray BE 2000). Enterococci are rare causes of eye infections, but are usually associated with poor visual outcome. In addition to complicating cataract extraction, enterococci are occasionally isolated from infected glaucoma filtering blebs (Leng et al. 2011).

2.3.1 The role of the cytolysin-A cytolysin or cytolytic toxin expressed by some $E$. faecalis strains renders infections refractory to combined antibiotic and anti-inflammatory therapy (Jett et al. 1995). In fact, experimental endophthalmitis initiated with cytolysinpositive $E$. faecalis showed no difference in disease course, regardless of whether antibiotic and or anti-inflammatory treatment was given. In contrast, parallel infections using isogenic mutants specifically defective in cytolysin expression were successfully treated with a combination of antibiotics and anti-inflammatory agents, but not with antibiotics alone, highlighting the contribution of inflammation to the course of endophthalmitis (Jett et al. 1995) (Fig. 2). This illustrates the importance of not only killing the bacterium causing infection, but also neutralizing toxins and controlling inflammation during the course of infection.

The $E$. faecalis cytolysin is encoded within a chromosomal pathogenecity island, or by large pheromone-responsive plasmids, such as pAD1 (Shankar et al. 2004). The cytolysin operon, regulated by a quorum sensing system, consists of eight genes arranged in two divergent transcripts. One transcript encodes the two toxin subunit precursors, CylL $\mathrm{L}_{\mathrm{L}}$ and $\mathrm{CylL}_{\mathrm{S}}$ (Fig. 3 ). Both toxin subunits are post-translationally modified by the product of the next gene in the operon, cylM. That modification includes the removal of hydroxyl groups from all serine and threonine residues in the subunits, and intramolecular ring formation with adjacent cysteines, resulting in the formation of the modified amino acids lanthionine and $\beta$ methyllanthionine. The post-translationally modified subunits, $\mathrm{CylL}_{\mathrm{L}} *$ and $\mathrm{CylL}_{\mathrm{S}} *$ are 
secreted by the product of the next gene in the transcript, $c y l B$, an ATP-binding cassette transporter. Both subunits are proteolytically trimmed co-secretionally, resulting in the extracellular forms CylL $_{\mathrm{L}}$ ' and CylL $\mathrm{L}_{\mathrm{S}}$. At this stage in maturity, neither subunit possesses detectable cytolytic activity. Both subunits are finally activated extracellularly by an additional proteolytic trimming step catalyzed by the product of the next gene in the operon, cylA, which encodes an independently secreted serine protease (Haas et al. 2002). CylL $\mathrm{L}_{\mathrm{L}}$,, the fully processed form of the larger toxin subunit, upon final proteolytic trimming, readily inserts into the membrane of target cells. CylL $\mathrm{S}_{\mathrm{S}}$, the fully processed form of the smaller subunit, has a lower affinity for target cell membranes, so transiently occurs in the free form in stoichiometric excess. This excess is sensed by the products of the cytolysin regulatory genes, CylR1 and CylR2, encoded on a divergent transcript. Detection of increased CylL" results in derepression of the operon and increased cytolysin expression. In the absence of target cells, CylL" and CylL $\mathrm{L}_{\mathrm{L}}$ " avidly bind to each other, rendering them incapable of insertion into membranes, and CylL $\mathrm{S}_{\mathrm{S}}$ incapable of signaling. By this mechanism, the cytolysin is only expressed at high levels when target cells are present (Coburn et al. 2004). Conceivably, therapeutics could be designed around dominant negative forms of $\mathrm{CylL}_{\mathrm{L}}$ " that would bind CylL $\mathrm{S}_{\mathrm{S}}$ but be incapable of membrane insertion, or CylA may be targeted to block toxin maturation.

2.3.2 The role of the proteases- $-E$. faecalis possesses another quorum regulated system that regulates expression of proteases GelE and SprE, and is organizationally similar to the staphylococcal agr locus (Qin et al. 2000) (Fig. 1). Termed the fsr locus, four agr homolgs, fsr $A, B, C$ and $D$ are endoded by the operon. FsrD is ribosomally synthesized, post-translationally processed, and secreted, and the mature quorum signal is termed gelatinase biosynthesis-activating pheromone (GBAP). The FsrD propeptide is processed by a cysteine protease domain on FsrB in a manner similar to the processing of $S$. aureus autoinducing peptide, AgrD. FsrD is then transported outside the cell for quorum sensing (Nakayama et al. 2006). GBAP accumulates outside the cell until it reaches a threshold level, at which point transcription of the gelE-sprE operon is induced generating GelE/ gelatinase and the serine protease SprE, and also autoinducing transcription of the fsroperon itself (Nakayama et al. 2001). GelE, a zinc metalloprotease capable of hydrolyzing collagen, casein, hemoglobin and other polypeptides, is produced mainly in late log to early stationary phases (Barrett et al. 1998). In experimental endophthalmitis, deleting gelE, sprE or both resulted in measurable attenuation of endophthalmitis, with gelE deletion having a greater effect than deleting $s p r E$ alone. However, $f_{s r}$-deficient mutants showed a greater degree of attenuation suggesting additional effects of $f_{s r}$ (Engelbert et al. 2004). GelE and SprE recently have been shown to have specific roles in mediating $E$. faecalis autolysis and biofilm formation (Thomas et al. 2008). E. faecalis can form biofilms on intraocular lens material (Kobayakawa et al. 2005). The contribution of the $f_{s} r$ system to biofilm formation was first shown by Hancock and Perego (Hancock and Perego 2004), who systematically knocked out each of the non-lethal two component signaling systems of E. faecalis. An interplay between GelE and SprE, and an E. faecalis autolysin, results in the release of high molecular weight extracellular (e)DNA, a by-product of cell lysis that is an important structural component of enterococcal biofilms (Thomas et al. 2008). The contribution of $f_{s} r$ and gelatinase to biofilm formation in vivo was supported by the observation of smaller vegetations produced by defective mutants in an endocarditis model (Hancock and Perego 2004). GelE also appears to modulate the immune response to $E$. faecalis in an endocarditis infection model through its ability to cleave the anaphylatoxin complement C5a causing decreased neutrophil migration to the infection sites (Thurlow et al. 2010). We believe that the contribution of the proteases to cell lysis also likely enhances inflammation, which may explain some of the additional attenuation noted above for the $f s r$ mutant in the endophthalmitis model. Some evidence suggests that these proteases also may play a role in 
the translocation of $E$. faecalis from the anterior chamber to the posterior segment, and contributing to retinal damage (Suzuki et al. 2008).

\subsection{Streptococcus pneumonia and other streptococci}

Streptococci are important causes of eye infections, especially endophthalmitis, with oral streptococci referred to as "viridians streptococci" or alpha hemolytic streptococci being especially common and severe (Chen et al. 2011, Mao et al. 1992). Streptococci accounted for almost $10 \%$ of post-cataract endophthlamitis cases in the Endophthalmitis Vitrectomy Study, and those cases had an especially poor outcome (EVS 1996). This included for historic reasons group D streptococci, the enterococci, as well as oral streptococci (often termed viridians streptococci) and pathogenic streptococci, including $S$. pyogenes, $S$. agalactiae, and $S$. pneumoniae. It remains unclear why streptococci produce such fulminant infections in the eye, while they often exist among the commensal flora of the oral cavity and nasopharynx. Viridans streptococci, such as $S$. mutans, $S$. sanguis, and $S$. mitis, have been reported to reach the eye endogenously after dissemination from endocarditis (Seles and Lang 2007), from local contamination following eye surgeries, and following ocular trauma complicating dental procedures (Blum-Hareuveni et al. 2006, Lamont and Booth 2006). Despite the blinding potential of this class of organisms, not much is known about their pathogenecity for the eye and this represents an important knowledge gap.

\subsubsection{Pathogenesis of S. pneumoniae endophthalmitis-Streptococcus}

pneumoniae is evolutionarily related to the oral streptococci, and there is some understanding of the pathogenesis of endophthalmitis due to this species. S. pneumoniae endophthalmitis can occur following any insult to the eye, but is most commonly encountered as a leading cause of bleb-associated endophthalmitis (Leng et al. 2011, Mac and Soltau 2003). Filtering blebs are surgically created defects in the sclera that allow excess aqueous humor to leak out of the eye in cases of glaucoma that are unresponsive to medical therapy. Bleb-related endophthalmitis typically occurs abruptly, months to years postoperatively, often after the bleb appears inflamed and the visual outcome is usually very poor even with prompt treatment (Leng et al. 2011).

S. pneumoniae expresses several virulence factors. The two most studied in relation to eye infection are pneumolysin and a cell wall hydrolase, autolysin. Pneumolysin is a member of the cholesterol-dependent, thiol-activated cytolysin family (Kanclerski and Mollby 1987), with structural similarities to other members of the family secreted by other gram positive pathogens (Tweten 2005), but is unique in lacking a signal peptide for secretion. This cytolysin binds to the host cell cytoplasmic membrane in a cholesterol-dependent manner, followed by formation of macromolecular assemblies and then pore formation resulting in lysis of neutrophils, red blood cells and platelets (Paton et al. 1997, Tweten 2005). At low doses, it can inhibit the respiratory burst of neutrophils and phagocytic capacity. It inhibits neutrophil chemotaxis and migration (Paton and Ferrante 1983). Independent from its cytolytic role, pneumolysinalso activates complement through the classical activation pathway by binding the Fc region of $\operatorname{IgG}$ (Paton et al. 1997), and interferes with opsonization, phagocytosis and killing. Pneumolysin is unusual in being produced in the cytoplasm and released by a process termed allolysis, where by competent cells cause the lysis of the noncompetent cells in the vicinity (Guiral et al. 2005, Gilmore and Haas 2005). Allolysis requires a two-peptide bacteriocin, $\mathrm{CibAB}$ that causes lysis through three cell wall hydrolases. For the pneumolysin to be released, it was found that a quorum sensor termed competence-stimulating peptide (CSP) is required (Guiral et al. 2005, Havarstein et al. 1995a) (Fig.1). Upon accumulation in the medium, CSP stimulates ComDE (Pestova et al. 1996), a two-component regulator, inducing the expression of the competence regulon. ComC encodes pre-CSP that is cleaved by an ATP-binding transporter, ComAB, during 
export. CSP now can bind the membrane-kinase ComD and activate, through phosphorylating itself and ComE, gene transcription (Havarstein et al. 1995b, Hui et al. 1995). Autolysin is another enzyme involved in inflammation. It is located in the cell envelope and is involved in the metabolism and degradation of the peptidoglycan backbone of the cell wall. It also causes the liberation of inflammation-inducing cell wall fragments during infection ( $\mathrm{Ng}$ et al. 2002).

Studies to characterize the role of pneumolysin and autolysin in endophthalmitis showed that strains deficient in pneumolysin expression resulted in infections with reduced intraocular inflammation early in infection, but with few differences from the wild type after 48 hours. Autolysin deficient strains caused a lower level of inflammation throughout (Ng et al. 2002). The contribution of these two virulence factors has been demonstrated in meningitis, where strains deficient in either showed significantly attenuated disease (Hirst et al. 2008).

2.4.2 Other pneumococcal factors-In addition to pneumolysin and autolysin, other pneumococcal factors such as neuraminidase and hyaluronatelyase may also contribute to the pathogenesis of endophthalmitis. Neuraminidase exists in two forms, NanA and NanB, that cleave the terminal sialic acid residues of glycoproteins and glycolipids on the cell surfaces, exposing receptors and enhancing adhesion (Krivan et al. 1988). In a murine meningitis model, it was shown that NanA is necessary and sufficient to promote $S$. pneumoniae adherence and invasion of the brain microvascular endothelial cells (Uchiyama et al. 2009). Hyaluronatelyase hydrolyzes hyaluronan, which is prevalent in the retina, choroid, trabecular meshwork, aqueous and vitreous humor (Lerner et al. 1997, Murata and Horiuchi 2005). Moreover, hyaluronan was identified as part of a signaling system that is involved in maintaining the functional structure of the retina and choroid (Murata and Horiuchi 2005). In meningitis, the laminin-receptor was found to be important for $S$. pneumoniae to bind cells that form the blood-brain-barrier, and consequently for invasion (Orihuela et al. 2009). It is interesting to speculate that polymorphisms in laminin may predispose to blood barrier infections, such as meningitis and endogenous endophthalmitis. Much can be learned from meningitis studies, including the importance of inflammation management when there is a high index of suspicion of the offending organism.

Dexamethasone before or concurrent with the first dose of intravenous antibiotics, for example, decreased the mortality in adults with acute pneumococcal meningitis (van de Beek 2009). Whether the addition of corticosteroids improves outcome in acute bacterial endophthalmitis is not yet clear.

\subsection{Bacillus}

Bacillus species cause an explosive, rapidly blinding endophthalmitis usually following trauma, with $70 \%$ of the eyes losing all useful vision (David et al. 1994). The presence of Bacillus in the eye results in an intense and rapid inflammatory reaction.

2.5.1 B. cereus and the eye-Bacillus cereus is the most common Bacillus species identified in cases of endophthalmitis. Available evidence points to a complex interplay between secreted factors and the host response, with a yet unidentified link to explain the rapid course of the disease. $B$. cereus has 4 identified membrane damaging toxins: hemolysin BL, phosphatidylinositol-specific phospholipase C, sphingomyelinase and phosphatidylcholine-specific phospholipase $\mathrm{C}$. The sphingomyelinase and phospholipase $\mathrm{C}$ are part of the cereolysin $\mathrm{AB}$ toxin that act sequentially to cause lysis of the cell membrane (Gilmore et al. 1989). The multi subunit hemolysin BL is a membrane-lytic toxin that also causes vascular permeability, ocular toxicity, and contributes to enteric disease (Callegan et al. 2002a, Callegan et al. 2002c, Callegan et al. 2003). In endophthalmitis, however, 
hemolysin BL only contributes measurably to pathogenesis early in the course of eye infection (Callegan et al. 1999b). Phosphatidylcholine-phospholipase C, part of the cytolyic unit of cereolysin $\mathrm{AB}$, was found to have no effect on the course or severity of experimental endophthalmitis. The role of other lipases, enterotoxins and proteases expressed by $B$. cereus remain to be determined. After ocular infection with B. cereus, neutrophils, emerging from the vasculature of the optic nerve head, were identified as early as 4 hours post infection (Ramadan et al. 2006). In addition, an increase in blood ocular barrier permeability was found where leakage of albumin and fibrin occurred as early as 8 hours after infection, and the tight junction disruption at the level of the retinal pigment epithelium began after 4 hours, accompanied by an increase in cytokines along the course of the infection (Moyer et al. 2009).

2.5.2 Quorum sensing in B. cereus: plcR-B. cereus virulence is clearly multifactorial, and it has proven challenging to dissect specific roles for various factors. To attempt to address a number of virulence factors en bloc, mutants in the quorum sensing system $p l c R$, which regulates expression of membrane damaging toxins, cell surface proteins and enzymes, were tested in rabbit endophthalmitis (Callegan et al. 2003). The plcR mutant was found to be significantly attenuated with decreased toxin expression, decreased motility, and significantly slower evolution of disease; however retinal damage was still evident and severe (Callegan et al. 2003). The quorum regulator PapR, a 48 amino acid autoinducer peptide, regulates the $p l c R$ regulon, leading to a decrease in hemolytic activity and virulence for insects, the natural host for B. cereus infection (Slamti and Lereclus 2002). Cytolysins regulated by $p l c R$ did not detectably affect retinal pigment epithelium cytotoxicity, indicating that $B$. cereus-induced permeability of the blood retina barrier is largely independent of plcR-regulated toxins (Moyer et al. 2008).

2.5.3 Motility and its contribution to virulence-Bacillus cereus is unique among the common causes of endophthalmitis because of its motility - it can migrate from the site of injection to involve all layers of the eye, from retina to anterior segment, within 12 hours (Callegan et al. 2002a). Non-motile strains injected into the vitreous do not migrate to the anterior segment, but posterior segment disease and retinal inflammation are still explosive (Callegan et al. 2006). Non-motile strains deficient in toxin production, proved less virulent and elicited slower evolution of retinal function loss and intraocular inflammation (Callegan et al. 2005, Callegan et al. 2006). At the cellular level, toxin production by B. cereus near or within the retina results in loss of retinal architecture and disruption of Müller cells, the major glial cells of the retina involved in structural support and retinal homeostasis control (Ramadan et al. 2006). Bacillus cereus strains capable of swarming express the highest level of hemolysin, suggesting that swarming and virulence factor production are related (Ghelardi et al. 2007). Oxygen is likely the substance driving $B$. cereus chemotaxis, attracting them away from the a cellular central vitreous to the highly vascularized periphery of the eye including the retina (Callegan et al. 2006). In summary, there appears to be a close association between motility, swarming and virulence factor production, but the basis for the unique virulence of $B$. cereus in endophthalmitis is far from solved.

\section{Host factors}

Despite the wealth of research on the molecular pathogenesis of infections at other anatomical sites, such as endocarditis and meningitis, our understanding of host/microbe interactions in the immune privileged eye is still in its infancy but holds considerable promise for the development of new therapeutic approaches for endophthalmitis. Optimization of the expression and activity of endogenous antimicrobial factors of the innate immune system could provide a path for improved therapy. For example, RegIII $\gamma$, a secreted lectin active against gram-positive bacteria expressed by intestinal cells (Cash et al. 
2006) and possibly others, regulates the abundance of gram positive flora on mucosal surfaces. Interestingly, it has been found to be downregulated in the intestines of mice after treatment with antibiotics (Brandl et al. 2008) as the result of the elimination of flagellated gram negatives, which gratuitously stimulate its production through TLR5 (Kinnebrew et al. 2010). Similar host antimicrobials are present at various anatomical sites, including the ocular surface, but little is known of their occurrence or role in the uveal tract.

\subsection{Anterior Chamber Acquired Immune Deviation}

The aqueous humor is contaminated by bacteria at a high rate after cataract surgeries as shown by some studies (Bausz et al. 2006, Dickey et al. 1991, Parmar et al. 2006), yet the rate of endophthalmitis after this procedure remains as low as $0.01-0.3 \%$ (Endophthalmitis Study Group, European Society of Cataract \& Refractive Surgeons 2007, Miller et al. 2005, Taban et al. 2005). This is prima facie evidence that despite immune privilege, which has been well studied in other contexts, innate defense to bacterial establishment and growth, remains at least partially intact. Immune privilege of the eye is achieved by the concerted actions of immune modulators including TGF- $\beta$, Fas ligand, a-MSH and others, thus limiting inflammatory reactions in the eye and preserving clarity of the visual axis during infection elsewhere in the body (Streilein 2003), but potentially leaving the eye vulnerable to infection. Immune privilege has both systemic and localized mechanisms of modulation. An arc of systemic suppressive mechanisms has been organized into what has been termed anterior chamber-associated immune deviation (ACAID). ACAID is established first by F480 macrophages acquiring antigen within the immune privileged eye, migrating to the spleen and presenting intraocular antigens to lymphocytes. As a result of experiencing the immunomodulatory environment of the eye, the macrophage orchestrates antigen-specific immunological tolerance mediated by efferent suppressor CD8 T cells, and potential afferent regulatory $\mathrm{T}$ cells. The soluble immunomodulating factors of the immune privileged ocular microenvironment themselves inhibit the activation of effector $\mathrm{T}$ cells and cytotoxic $\mathrm{T}$ cell activity, while promoting the induction and activation of regulatory $\mathrm{T}$ cells. These systemic and localized mechanisms of immunomodulation protect the eye from the inflammation, and from the induction of autoimmune disease targeting the retinal proteins expressed within its sequestered microenvironment (Taylor 2009). The precise mechanisms by which antimicrobial defenses function in this carefully regulated milieu is largely unexplored, but there is evidence for low level expression of defensins.

Maintenance of ocular immune privilege is required for preserving a clear visual axis free of inflammation, however, imbalances that lead to inflammation happen not only following infection but also as a consequence of systemic autoimmune and inflammatory disease (some of which are now being associated with infection, such as sarcoidosis (Song et al. 2005), Behcet's disease (Yanagihori et al. 2006), and inflammatory bowel diseases (Friswell et al. 2010)). The innate immune system is believed to play an important role in triggering systemic autoimmune diseases as well as development of uveitis. Most eye tissues express toll-like receptors (Chang et al. 2006). Eyes injected with TLR agonists induce uveitis through the induction of cytokine synthesis (Allensworth et al. 2011). In addition to the presence of microbial component receptors, macrophages and dendritic cells in the uveal tract are part of the innate immune system (McMenamin et al. 1994). Typically, uveitis is induced in experimental models using endotoxin, specifically lipopolysaccharides (LPS) that are a major component of the cell wall of gram-negative bacteria. Inflammation usually occurs $24 \mathrm{~h}$ following LPS injection, with the posterior compartment also being susceptible (Koizumi et al. 2003). The relevance of experimental endotoxin induced uveitis to human uveitis is debated, although evidence is emerging that systemic diseases associated with uveitis, including IBD and ankylosing spondylitis, might be due to shifts in bowel flora (Friswell et al. 2010, Strober 2010), and that infections by microbes such as Salmonella, 
Yersinia and Chlamydia (Huhtinen et al. 2001, Wakefield et al. 1990) are associated with reactive arthritis in HLA-B27-positive patients. It is clear that even the most basic components of bacterial cells contribute to ocular inflammation in bacterial endophthalmitis as well as other inflammatory conditions.

\subsection{Defense of the posterior segment despite immune privilege}

Despite the restricted immunity of the eye, several lines of defense against infection have been defined. The anatomic barrier provided by an intact lens posterior capsule is important for limiting the spread of bacteria to the vulnerable posterior segment (Beyer et al. 1984). The lens capsule is held by zonules that are porous and likely allow for communication between anterior and posterior compartment fluids, especially when pressure in the anterior chamber rises such as during a cataract surgery. Defensins are expressed in the vitreous, but appear to occur at too low a level to be antimicrobial (Haynes et al. 2000). Although complement had been proposed to play a role in posterior segment defense, direct experimentation using $\mathrm{C}^{-/-}$knockout mice found no increase in susceptibility to infection compared to wild type mice (Engelbert and Gilmore 2005). Fas ligand (FasL) was found to enhance defense, potentially by activating either resident cells or the first wave of neutrophils (Engelbert and Gilmore 2005). This conclusion was based on the observation that FasL deficient B6 mice exhibited susceptibility to infection at infective doses to which wild type mice were resistant.

The retina appears to possess an intrinsic ability to protect itself from inflammatory damage. Alpha-B crystalline, a heat shock protein constitutively expressed in the neural retina and retinal pigment epithelium, appears to contribute to host defense by preventing apoptosis of retinal cells, by inhibiting the activation of caspase 3. S. aureus appears to be able to overcome this protection by inducing the cleavage and inactivation of alpha $\mathrm{B}$ crystalline (Whiston et al. 2008).

\subsection{Toll-like receptor (TLR) involvement in host response}

TLRs that trigger innate immunity in response to bacterial ligands have begun to be examined in the context of endophthalmitis. S. aureus and the TLR-2 ligand Pam-3-Cys induce inflammatory cytokine expression in mice, as well as trigger responses specifically in Müller cells (Chang et al. 2006, Shamsuddin and Kumar 2011). TLR-2 also plays an important role in the initial ocular response to B. cereus endophthalmitis (Shamsuddin and Kumar 2011). Immunomodulatory factors involved in maintaining immune privilege, such as a-MSH (Taylor et al. 1992), have been found to modify some TLR-mediated signaling. a-MSH, a neuropeptide involved in blocking inflammation in the eye and maintaining immune privilege, antagonizes TLR-4 signaling by triggering interleukin-1 receptorassociated kinase M (IRAK-M) to bind IRAK-1 in the TLR signaling pathway, preventing activation of the inflammatory cascade (Taylor 2005).

\subsection{Tumor necrosis factor alpha (TNF- $\alpha$ )}

TNF- $\alpha$ contributes to the explosive host response to $B$. cereus, resulting in blood-retina barrier breakdown. It is secreted by macrophages and neutrophils, and results in the upregulation of cell adhesion molecules, particularly selectins, on vascular endothelial cells (Rosen 2004, Rosenfeld et al. 2006, Whiston et al. 2008). TNF-a increases vascular permeability and induces mononuclear phagocytes to produce cytokines IL-1 and IL-6. As a result, neutrophils rapidly chemotax through the reduced blood-retina barrier into the vitreous (Bazzoni and Beutler 1996, Crane and Liversidge 2008). TNF- $\alpha$ is upregulated in parallel with neutrophil influx in $B$. cereus endophthalmitis. B. cereus experimental endophthalmitis in homozygous TNF-a knockout mice replicated faster that in the wild type 
mice, elicited less neutrophil infiltration into the vitreous, and precipitated a more severe drop in electroretinographic response (Ramadan et al. 2008).

\section{Anti-inflammatory therapy: Thecontroversy}

The value of corticosteroids and other anti-inflammatory drugs for treating endophthalmitis continues to be debated. Anti-inflammatory agents function by inhibiting migration of macrophages, stabilizing vascular membranes, and blocking inflammatory mediators. In endophthalmitis, a correlation has been demonstrated between the level of expression of inflammatory mediators TNF- $\alpha$, IL- $1 \beta$ and IFN- $\gamma$ and endophthalmitis clinical inflammation scores (Petropoulos et al. 2006). In acute bacterial meningitis - a condition with parallels to bacterial endophthalmitis - adjunctive corticosteroids are beneficial (de Gans et al. 2002). These factors establish a rationale for the potential benefit of using corticosteroids as adjunctive treatment of bacterial endophthalmitis. However, demonstration of efficacy has met with mixed results with respect to reducing postoperative inflammation, improving visual outcome, and influencing potency and availability of coadministered antibiotics. Response to intravitreal anti-inflammatories has been directly examined in rabbit models of endophthalmitis caused by staphylococci, streptococci, bacilli and enterococci. These studies have assessed clinical scores, histology and sometimes electroretino graphic changes. Results vary widely, with some studies demonstrating benefit, others showing no effect, and still others showing worse outcomes:

1. Use of steroids alone without antibiotics was found to render the eye more susceptible to infection, and impedes the immune response (Bucher et al. 2005).

2. Early administration of intravitreal corticosteroids with vancomycin and other antibiotics for the treatment of gram positive bacterial infection was found to help resolve inflammation and infection, and salvage vision (Bucher et al. 2005, De Kaspar et al. 2008, Jett et al. 1995, Liu et al. 2011, Liu et al. 2008) (Fig. 2). The use of biodegradable polymers mixed with vancomycin, amikacin, and dexamethasone as scleral plugs for treatment of endophthalmitis was found to deliver high concentrations of drugs in vivo in experimental endophthalmitis over an extended period of time without any major complications (Peng et al. 2010).

3. Use of corticosteroids as adjuncts to antibiotics including fluoroquinolones was found not to influence outcome (Ermis et al. 2005, Ermis et al. 2007, Yildirim et al. 2002)

4. Use of adjunctive steroids in some endophthalmitis models was found to reduce the efficacy of antibiotics (Smith et al. 1991, Wiskur et al. 2008), and in some cases contributed to an increase in ocular inflammation and retinal necrosis following injection (Meredith et al. 1996).

Clinical studies have similarly failed to reach consensus on the benefit of adjunctive antiinflammatory use. Inconsistency stems from differences in study design, sample size, causative organism, and treatment methods used. A retrospective study of endophthalmitis due to coagulase negative staphylococci found that good visual outcome was associated with intensive topical corticosteroid during the symptomatic period (Ormerod et al. 1993). A prospective placebo controlled series of 29 patients with acute postoperative endophthalmitis was conducted where half received $0.4 \mathrm{mg}$ of intravitreal dexamethasone in addition to the intravitreal antibiotics $(0.2 \mathrm{mg}$ vancomycin and $0.05 \mathrm{mg}$ gentamicin) received by all patients. Those receiving the antibiotic with dexamethasone showed a trend toward better visual outcome, although this did not achieve statistical significance (Gan et al. 2005b). Vancomycin levels were similar in both groups and did not appear to be affected by dexamethasone co administration (Gan et al. 2005a). Das et al. (Das et al. 1999) 
conducted a prospective randomized trial on 63 patients to evaluate the efficacy of intravitreal dexamethasone co-administered with antibiotic, along with vitrectomy, for treating exogeneous bacterial endophthalmitis. Dexamethasone was found to reduce inflammation early, but had no independent influence on the visual outcome (Das et al. 1999). A more recent prospective double blind trial randomized 62 patients with endophthalmitis following cataract surgery, bleb infection and other causes, to receive intravitreal ceftazidime $(2.225 \mathrm{mg} / 0.1 \mathrm{ml})$ and vancomycin $(1 \mathrm{mg} / 0.1 \mathrm{ml})$, plus either dexamethasone $(0.4 \mathrm{mg} / 0.1 \mathrm{ml})$ or placebo. No significant difference in visual outcome was observed, however subgroup analysis found a trend to better visual acuity in the postcataract/dexamethasone-treated subgroup (Albrecht et al. 2011). In contrast, Shah et al. (Shah et al. 2000) conducted retrospective analysis of 57 patients with postoperative endophthalmitis who received intravitreal amikacin $(0.4 \mathrm{mg} / 0.1 \mathrm{ml})$ and vancomycin $(1 \mathrm{mg} /$ $0.1 \mathrm{ml}$ ) at the time of vitrectomy or vitreous aspirate, and analyzed cohorts based on whether or not they had also received dexamethasone $(0.4 \mathrm{mg} / 0.1 \mathrm{ml})$. They found that patients who received intravitreal dexamethasone had a significantly reduced probability of a three-line improvement in visual acuity (Shah et al. 2000). Patient treatment was non-random and depended on physician preference, which raises the possibility of bias in administering antiinflammatory therapy in more severe cases where the chances of improvement may have been lower a priori. In summary, it is difficult to draw unambiguous conclusions about the value of anti-inflammatory adjunctive treatment for acute bacterial endophthalmitis based on existing animal and human studies. A large, well-constructed randomized trial will be necessary to resolve this question.

\section{Prophylaxis}

Prophylaxis is an important consideration for any globe penetrating surgical procedure, including intravitreal injection and intraocular surgery, given the potential consequence of bacterial endophthalmitis. However, the low incidence of endophthalmitis, the rapid evolution of surgical techniques, and the difference in practice patterns, all make it difficult to perform or compare controlled studies that attempt to measure efficacy of prophylactic measures. Prophylactic measures generally fall into two categories: 1) Use of mainly topical antiseptics with a broad antimicrobial activity, and 2) Use of perioperative antibiotics that have a targeted antimicrobial spectrum. The value of preoperative, intraoperative and postoperative prophylactic measures has been studied in humans as well as in animals, although there are few randomized prospective trials.

\subsection{Evidence from clinical studies}

The use of 5\% povidone-iodine in the conjunctival cul de sac was found to be effective for preventing postoperative endophthalmitis (Ferguson et al. 2003, Mino de Kaspar et al. 2005, Speaker and Menikoff 1991) through decreasing conjunctival bacterial numbers (Ferguson et al. 2003, Wu et al. 2006), and is included among best practices by the American Academy of Ophthalmology (American Academy of Ophthalmology 2011). Systemic, topical, subconjunctival and intracameral antibiotics are also used for prophylaxis, but there have been few randomized controlled studies that unambiguously prove benefit. Topical antibiotics for surgical prophylaxis have been widely used, but there have been no randomized placebo-controlled trials (Chang et al. 2007). Fluoroquinolones, such as moxifloxacin and gatifloxacin, are most widely used, and have good ocular penetration with few side effects (Gungor et al. 2011, Ong-Tone 2007). Besifloxacin, a recently approved fluoroquinolone developed for ophthalmic use, has been approved for treatment of conjunctivitis, and appears also to achieve good ocular penetration (Yoshida et al. 2010). When comparing an immediate application of povidone-iodine with or without a preinjection antibiotic, no additional benefit was found in adding the antibiotic (Moss et al. 2009). As antimicrobial resistance in the conjunctival flora was found to increase after 
repeated antibiotic exposure (Kim and Toma 2011), there is some concern for the selection of resistant organisms through the extensive use of prophylactic antibiotics.

The prophylactic use of intraocular antibiotics received support from the results of the European Society of Cataract and Refractive Surgeons (ESCRS) study (Endophthalmitis Study Group, European Society of Cataract \& Refractive Surgeons 2007). This study was a prospective, randomized, partially masked, multicenter trial that examined the effect of intracameral cefuroxime injected at the end of the surgery, with or without perioperative levofloxacin. The study included 8,103 patients who received prophylactic intracameral cefuroxime, and as many who did not. The arm not receiving intracameral cefuroxime had a 4.92 fold increased risk of developing postoperative endophthalmitis (C.I. 1.87-12.9) (Endophthalmitis Study Group, European Society of Cataract \& Refractive Surgeons 2007). The study was terminated early because of this beneficial effect. Other studies in Europe also reported a benefit from the use of intracameral cefuroxime orcefazolin in reducing the incidence of postoperative endophthalmitis (Montan et al. 2002, Romero et al. 2006, Wejde et al. 2005, Yu-Wai-Man et al. 2008). Among intracameral antibiotics tested, cefuroxime was found in one study to be the most cost-effective for prevention of postoperative endophthalmitis (Sharifi et al.2009). Intracameral cefuroxime prophylaxis is now common in Europe, with $61 \%$ of surveyed ophthalmologic units in the United Kingdom using it in 2010 (Murjaneh et al. 2010). It is unclear how the rates of endophthalmitis in the ESCRS, and some of the other studies, which were higher than those routinely reported in the US, might have affected the outcomes of these studies. The use of intracameral cefuroxime in the USA is less common, partly because of the lack of commercially available ophthalmic formulation, and because of difference in the incidence of postoperative endophthalmitis (Wykoff et al. 2010).

\subsection{Animal studies and novel approaches}

New approaches for prophylaxis are being tested. An intracameral vancomycin microparticle injection at the time of insertion of a contaminated intraocular lens into the anterior chamber of a rabbit, was found to reduce the rate of endophthalmitis without detectable toxic effect, and showed maintenance of antibiotic concentrations above MIC levels for at least 6 hours (Kodjikian et al. 2010). Subconjunctival injection of triamcinolone with ciprofloxacin hydrochloride as compared to $0.3 \%$ topical ciprofloxacin hydrochloride showed equal efficacy when used in experimental $S$. aureus endophthalmitis in rabbits suggesting that the subconjunctival route of antibiotic delivery might be a way to decrease non-compliance (Cardillo et al. 2010). Other experimental therapies that are being studied include the application of bacteriophage lysins to rapidly decontaminate an environment after surgery. Bacteriophages produce lysins that rupture the bacterial cell wall, leading to release of its phage progeny (Vandersteegen et al. 2011). Staphylococcal phage lyins are being explored for therapy as well as eradication of $S$. aureus from different sites of infection (Pastagia et al. 2011). Antipneumococcal lysins have also been used to treat experimental S. pneumoniae pneumonia (Witzenrath et al. 2009) and meningitis (Grandgirard et al. 2008). With a current rate of postoperative endophthalmitis ranging from $0.01-0.3 \%$, depending on center (Endophthalmitis Study Group, European Society of Cataract \& Refractive Surgeons 2007, Taban et al. 2005), an extremely large study would be required to prove efficacy of a prophylactic measure. This poses a formidable barrier to proving the value of prophylaxis in an era of evidence-based medicine.

\section{Future directions and perspectives}

Research questions that still need to be addressed include among others:

1. Factors related to the host/bacterial relationship in the eye 
a. What are the critical determinants of outcome in endophthalmitis? Since bacteria vary widely in virulence, are any of the principles generalizable? How exactly is the blood-retinal barrier maintained and regulated, and can it be manipulated to manage the course of disease? How do retinal cell death pathways differ when the effector is inflammation versus bacterial toxins?

b. In an increasingly aged patient population, with growing rates of type-2 diabetes, what aspects of the host response contribute to susceptibility to bacterial endophthalmitis?

c. How is host response to infection in the immune privileged eye similar and different from the response at other sites of infection?

2. Clinical research

a. Given the rarity of the postoperative endophthalmitis, randomized controlled trials evaluating different antimicrobial prophylaxis protocols require a very large study population (usually thousands of patients in each study arm). Are there reasonable surrogate approaches for answering the question of optimal prophylaxis? Does vision loss resulting from treatment failure associated with antibiotic resistant microbes stem only from delay in eradication, or do these microbes exhibit increased virulence as well, as has been suggested for CA-MRSA?

3. Pharmacology research

a. How can our understanding of virulence and expression regulation aid in developing novel antimicrobials? Conceivably, therapeutics could be designed around many of the things discussed earlier in the review like: changes in the nutritional environment that can regulate virulence production as is the case with $\operatorname{cod} Y$ in $S$. aureus; the use of agr inhibitors in staphylococci to control virulence and biofilm formation/detachment and spread of infection; targeting CylA in E. faecalis to block toxin maturation; blocking hyaluronatelyase in $S$. pneumoniae from breaking hyaluronan that is abundant in ocular parts.

b. To what extent do new cell wall agents (inhibitors of $S$. aureus wall teichoic acid biosynthesis, phage lysin mediated release of bacterial DNA) mitigate or exacerbate inflammation, and to what extent does rapid bacterial killing limit damage in endophthalmitis?

\section{Conclusion}

Rapid growth in globe-penetrating procedures performed on an outpatient basis is fueling increased concern for intraocular infection. Because of proximity to the retina, endophthalmitis is always a therapeutic crisis and many cases result in significant vision loss. Research into microbial pathogenesis that can lead to better targeted strategies for preventing vision loss is therefore very important. A better understanding of the critical events in the pathogenesis of endophthalmitis could lead to new approaches for prevention and treatment that target bacterial quorum development, attachment, virulence factor expression, mechanisms of migration from anterior to posterior segment, and the host response. Technical advances in our ability to manipulate the microbe as well as model hosts are bringing us to the threshold of this understanding. 


\section{References}

Albrecht E, Richards JC, Pollock T, Cook C, Myers L. Adjunctive use of intravitreal dexamethasone in presumed bacterial endophthalmitis: a randomised trial. Br. J. Ophthalmol. 2011; 95:1385-1388. [PubMed: 21289020]

Allegretti M, Moriconi A, Beccari AR, Di Bitondo R, Bizzarri C, Bertini R, Colotta F. Targeting C5a: recent advances in drug discovery. Curr. Med. Chem. 2005; 12:217-236. [PubMed: 15638737]

Allensworth JJ, Planck SR, Rosenbaum JT, Rosenzweig HL. Investigation of the differential potentials of TLR agonists to elicit uveitis in mice. J. Leukoc. Biol. 2011; 90:1159-1166. [PubMed: 21934069]

American Academy of Ophthalmology Cataract and Anterior segment Panel. Cataract in the Adult Eye. San Francisco, CA: American Academy of Ophthalmology; 2011. Preferred Practice Pattern Guidelines. Available at: www.aao.org/ppp

Anand AR, Therese KL, Madhavan HN. Spectrum of a etiological agents of postoperative endophthalmitis and antibiotic susceptibility of bacterial isolates. Indian J. Ophthalmol. 2000; 48:123-128. [PubMed: 11116508]

Asbell PA, Sahm DF, Shaw M, Draghi DC, Brown NP. Increasing prevalence of methicillin resistance in serious ocular infections caused by Staphylococcus aureus in the United States: 2000 to 2005. J. Cataract Refract. Surg. 2008a; 34:814-818. [PubMed: 18471638]

Asbell PA, Colby KA, Deng S, McDonnell P, Meisler DM, Raizman MB, Sheppard JD Jr, Sahm DF. Ocular TRUST: nationwide antimicrobial susceptibility patterns in ocular isolates. Am. J. Ophthalmol. 2008b; 145:951-958. [PubMed: 18374299]

Baillif S, Ecochard R, Casoli E, Freney J, Burillon C, Kodjikian L. Adherence and kinetics of biofilm formation of Staphylococcus epidermidis to different types of intraocular lenses under dynamic flow conditions. J. Cataract Refract. Surg. 2008; 34:153-158. [PubMed: 18165096]

Bainbridge JW, Teimory M, Tabandeh H, Kirwan JF, Dalton R, Reid F, Rostron CK. Intraocular lens implants and risk of endophthalmitis. Br. J. Ophthalmol. 1998; 82:1312-1315. [PubMed: 9924340]

Barbier F. Methicillin-resistant coagulase-negative staphylococci in the community: high homology of SCCmec IVa between Staphylococcus epidermidis and major clones of methicillin-resistant Staphylococcus aureus. J. Infect. Dis. 2010; 202:270-281. [PubMed: 20550456]

Barrett AJ, Rawlings ND, Woessner JF. Handbook of proteolytic enzymes. 1998:350-369.

Bausz M, Fodor E, Resch MD, Kristof K. Bacterial contamination in the anterior chamber after povidone-iodine application and the effect of the lens implantation device. J. Cataract Refract. Surg. 2006; 32:1691-1695. [PubMed: 17010869]

Bazzoni F, Beutler B. The tumor necrosis factor ligand and receptor families. N. Engl. J. Med. 1996; 334:1717-1725. [PubMed: 8637518]

Beenken KE, Mrak LN, Griffin LM, Zielinska AK, Shaw LN, Rice KC, Horswill AR, Bayles KW, Smeltzer MS. Epistatic relationships between sarA and agr in Staphylococcus aureus biofilm formation. PLoS One. 2010; 5:e10790. [PubMed: 20520723]

Bekeredjian-Ding I, Inamura S, Giese T, Moll H, Endres S, Sing A, Zahringer U, Hartmann G. Staphylococcus aureus protein A triggers T cell-independent B cell proliferation by sensitizing B cells for TLR2 ligands. J. Immunol. 2007; 178:2803-2812. [PubMed: 17312124]

Bera A, Biswas R, Herbert S, Kulauzovic E, Weidenmaier C, Peschel A, Gotz F. Influence of wall teichoic acid on lysozyme resistance in Staphylococcus aureus. J. Bacteriol. 2007; 189:280-283. [PubMed: 17085565]

Beveridge TJ, Makin SA, Kadurugamuwa JL, Li Z. Interactions between biofilms and the environment. FEMS Microbiol. Rev. 1997; 20:291-303. [PubMed: 9299708]

Beyer TL, Vogler G, Sharma D, O'Donnell FE Jr. Protective barrier effect of the posterior lens capsule in exogenous bacterial endophthalmitis--an experimental primate study. Invest. Ophthalmol. Vis. Sci. 1984; 25:108-112. [PubMed: 6607906]

Bischoff M, Dunman P, Kormanec J, Macapagal D, Murphy E, Mounts W, Berger-Bachi B, Projan S. Microarray-based analysis of the Staphylococcus aureus sigmaB regulon. J. Bacteriol. 2004; 186:4085-4099. [PubMed: 15205410] 
Blum-Hareuveni T, Rehany U, Rumelt S. Devastating endophthalmitis following penetrating ocular injury during night sleep from orthodontic headgear: case report and literature review. Graefes Arch. Clin. Exp. Ophthalmol. 2006; 244:253-258. [PubMed: 15999259]

Boles BR, Horswill AR. Staphylococcal biofilm disassembly. Trends Microbiol. 2011

Booth MC, Atkuri RV, Nanda SK, Iandolo JJ, Gilmore MS. Accessory gene regulator controls Staphylococcus aureus virulence in endophthalmitis. Invest. Ophthalmol. Vis. Sci. 1995; 36:18281836. [PubMed: 7635657]

Booth MC, Cheung AL, Hatter KL, Jett BD, Callegan MC, Gilmore MS. Staphylococcal accessory regulator (sar) in conjunction with agr contributes to Staphylococcus aureus virulence in endophthalmitis. Infect. Immun. 1997; 65:1550-1556. [PubMed: 9119503]

Brandl K, Plitas G, Mihu CN, Ubeda C, Jia T, Fleisher M, Schnabl B, DeMatteo RP, Pamer EG. Vancomycin-resistant enterococci exploit antibiotic-induced innate immune deficits. Nature. 2008; 455:804-807. [PubMed: 18724361]

Brian G, Taylor H. Cataract blindness--challenges for the 21st century. Bull. World Health Organ. 2001; 79:249-256. [PubMed: 11285671]

Bucher RS, Hall E, Reed DM, Richards JE, Johnson MW, Zacks DN. Effect of intravitreal triamcinolone acetonide on susceptibility to experimental bacterial endophthalmitis and subsequent response to treatment. Arch. Ophthalmol. 2005; 123:649-653. [PubMed: 15883284]

Bunschoten A, Ippel JH, Kruijtzer JA, Feitsma L, de Haas CJ, Liskamp RM, Kemmink J. A peptide mimic of the chemotaxis inhibitory protein of Staphylococcus aureus: towards the development of novel anti-inflammatory compounds. Amino Acids. 2011; 40:731-740. [PubMed: 20683629]

Caiazza NC, O'Toole GA. Alpha-toxin is required for biofilm formation by Staphylococcus aureus. J. Bacteriol. 2003; 185:3214-3217. [PubMed: 12730182]

Callegan MC, Booth MC, Jett BD, Gilmore MS. Pathogenesis of gram-positive bacterial endophthalmitis. Infect. Immun. 1999a; 67:3348-3356. [PubMed: 10377112]

Callegan MC, Jett BD, Hancock LE, Gilmore MS. Role of hemolysin BL in the pathogenesis of extra intestinal Bacillus cereus infection assessed in an endophthalmitis model. Infect. Immun. 1999b; 67:3357-3366. [PubMed: 10377113]

Callegan MC, Kane ST, Cochran DC, Gilmore MS. Molecular mechanisms of Bacillus endophthalmitis pathogenesis. DNA Cell Biol. 2002a; 21:367-373. [PubMed: 12167238]

Callegan MC, Engelbert M, Parke DW 2nd, Jett BD, Gilmore MS. Bacterial endophthalmitis: epidemiology, therapeutics, and bacterium-host interactions. Clin. Microbiol. Rev. 2002b; 15:111124. [PubMed: 11781270]

Callegan MC, Cochran DC, Kane ST, Gilmore MS, Gominet M, Lereclus D. Contribution of membrane-damaging toxins to Bacillus endophthalmitis pathogenesis. Infect. Immun. 2002c; 70:5381-5389. [PubMed: 12228262]

Callegan MC, Kane ST, Cochran DC, Gilmore MS, Gominet M, Lereclus D. Relationship of plcRregulated factors to Bacillus endophthalmitis virulence. Infect. Immun. 2003; 71:3116-3124. [PubMed: 12761089]

Callegan MC, Kane ST, Cochran DC, Novosad B, Gilmore MS, Gominet M, Lereclus D. Bacillus endophthalmitis: roles of bacterial toxins and motility during infection. Invest. Ophthalmol. Vis. Sci. 2005; 46:3233-3238. [PubMed: 16123424]

Callegan MC, Novosad BD, Ramirez R, Ghelardi E, Senesi S. Role of swarming migration in the pathogenesis of bacillus endophthalmitis. Invest. Ophthalmol. Vis. Sci. 2006; 47:4461-4467. [PubMed: 17003440]

Camargo IL, Gilmore MS. Staphylococcus aureus--probing for host weakness? J. Bacteriol. 2008; 190:2253-2256. [PubMed: 18223088]

Cardillo JA, Paganelli F, Melo LA Jr, Silva AA Jr, Pizzolitto AC, Oliveira AG. Brazilian Ocular Pharmacology and Pharmaceutical Technology Research Group. Subconjunctival delivery of antibiotics in a controlled-release system: a novel anti-infective prophylaxis approach for cataract surgery. Arch. Ophthalmol. 2010; 128:81-87. [PubMed: 20065222]

Cash HL, Whitham CV, Behrendt CL, Hooper LV. Symbiotic bacteria direct expression of an intestinal bactericidal lectin. Science. 2006; 313:1126-1130. [PubMed: 16931762] 
Cavuoto K, Zutshi D, Karp CL, Miller D, Feuer W. Update on bacterial conjunctivitis in South Florida. Ophthalmology. 2008; 115:51-56. [PubMed: 17572497]

Cedergren L, Andersson R, Jansson B, Uhlen M, Nilsson B. Mutational analysis of the interaction between staphylococcal protein A and human IgG1. Protein Eng. 1993; 6:441-448. [PubMed: 8332602]

Centers for Disease Control and Prevention (CDC). Staphylococcus aureus resistant to vancomycin-United States, 2002. MMWR Morb. Mortal. Wkly. Rep. 2002; 51:565-567. Available at: http:// www.cdc.gov/mmwr/preview/mmwrhtml/mm5126a1.htm. [PubMed: 12139181]

Chambers HF. Methicillin resistance in staphylococci: molecular and biochemical basis and clinical implications. Clin. Microbiol. Rev. 1997; 10:781-791. [PubMed: 9336672]

Chang DF, Braga-Mele R, Mamalis N, Masket S, Miller KM, Nichamin LD, Packard RB, Packer M. ASCRS Cataract Clinical Committee. Prophylaxis of postoperative endophthalmitis after cataract surgery: results of the 2007 ASCRS member survey. J. Cataract Refract. Surg. 2007; 33:18011805. [PubMed: 17889779]

Chang JH, McCluskey PJ, Wakefield D. Toll-like receptors in ocular immunity and the immunopathogenesis of inflammatory eye disease. Br. J. Ophthalmol. 2006; 90:103-108. [PubMed: 16361678]

Chen E, Lin MY, Cox J, Brown DM. Endophthalmitis after intravitreal injection: the importance of viridans streptococci. Retina. 2011; 31:1525-1533. [PubMed: 21878800]

Cheng AG, DeDent AC, Schneewind O, Missiakas D. A play in four acts: Staphylococcus aureus abscess formation. Trends Microbiol. 2011; 19:225-232. [PubMed: 21353779]

Chhabra S, Kunimoto DY, Kazi L, Regillo CD, Ho AC, Belmont J, Maguire J, Vander J, Brown GC. Endophthalmitis after open globe injury: microbiologic spectrum and susceptibilities of isolates. Am. J. Ophthalmol. 2006; 142:852-854. [PubMed: 17056367]

Chien Y, Manna AC, Projan SJ, Cheung AL. SarA, a global regulator of virulence determinants in Staphylococcus aureus, binds to a conserved motif essential for sar-dependent gene regulation. J. Biol. Chem. 1999; 274:37169-37176. [PubMed: 10601279]

Coburn PS, Pillar CM, Jett BD, Haas W, Gilmore MS. Enterococcus faecalis senses target cells and in response expresses cytolysin. Science. 2004; 306:2270-2272. [PubMed: 15618522]

Corbin BD. Metal chelation and inhibition of bacterial growth in tissue abscesses. Science. 2008; 319:962-965. [PubMed: 18276893]

Cramton SE, Ulrich M, Gotz F, Doring G. Anaerobic conditions induce expression of polysaccharide intercellular adhesin in Staphylococcus aureus and Staphylococcus epidermidis. Infect. Immun. 2001; 69:4079-4085. [PubMed: 11349079]

Crane IJ, Liversidge J. Mechanisms of leukocyte migration across the blood-retina barrier. Semin. Immunopathol. 2008; 30:165-177. [PubMed: 18305941]

Das T, Jalali S, Gothwal VK, Sharma S, Naduvilath TJ. Intravitreal dexamethasone in exogenous bacterial endophthalmitis: results of a prospective randomised study. Br. J. Ophthalmol. 1999; 83:1050-1055. [PubMed: 10460774]

David DB, Kirkby GR, Noble BA. Bacillus cereus endophthalmitis. Br. J. Ophthalmol. 1994; 78:577580. [PubMed: 7918273]

De Beer D, Srinivasan R, Stewart PS. Direct measurement of chlorine penetration into biofilms during disinfection. Appl. Environ. Microbiol. 1994; 60:4339-4344. [PubMed: 7811074]

De Gans J, van de Beek D. European Dexamethasone in Adulthood Bacterial Meningitis Study Investigators. Dexamethasone in adults with bacterial meningitis. N. Engl. J. Med. 2002; 347:1549-1556. [PubMed: 12432041]

De Kaspar HM, Ta CN, Engelbert M, Mette M, Thiel M, Kampik K. Effects of intravitreal corticosteroid in the treatment of Staphylococcus aureus-induced experimental endophthalmitis. Retina. 2008; 28:326-332. [PubMed: 18301039]

De Lencastre H, Wu SW, Pinho MG, Ludovice AM, Filipe S, Gardete S, Sobral R, Gill S, Chung M, Tomasz A. Antibiotic resistance as a stress response: complete sequencing of a large number of chromosomal loci in Staphylococcus aureus strain COL that impact on the expression of resistance to methicillin. Microb. Drug Resist. 1999; 5:163-175. [PubMed: 10566865] 
Deramo VA, Lai JC, Winokur J, Luchs J, Udell IJ. Visual outcome and bacterial sensitivity after methicillin-resistant Staphylococcus aureus-associated acute endophthalmitis. Am. J. Ophthalmol. 2008; 145:413-417. [PubMed: 18191097]

Diago T, McCannel CA, Bakri SJ, Pulido JS, Edwards AO, Pach JM. Infectious endophthalmitis after intravitreal injection of antiangiogenic agents. Retina. 2009; 29:601-605. [PubMed: 19357558]

Dickey JB, Thompson KD, Jay WM. Anterior chamber aspirate cultures after uncomplicated cataract surgery. Am. J. Ophthalmol. 1991; 112:278-282. [PubMed: 1882939]

Diep BA. Complete genome sequence of USA300, an epidemic clone of community-acquired meticillin-resistant Staphylococcus aureus. Lancet. 2006; 367:731-739. [PubMed: 16517273]

Dunman PM, Murphy E, Haney S, Palacios D, Tucker-Kellogg G, Wu S, Brown EL, Zagursky RJ, Shlaes D, Projan SJ. Transcription profiling-based identification of Staphylococcus aureus genes regulated by the agr and/or sarA loci. J. Bacteriol. 2001; 183:7341-7353. [PubMed: 11717293]

Endophthalmitis Study Group, European Society of Cataract \& Refractive Surgeons. Prophylaxis of postoperative endophthalmitis following cataract surgery: results of the ESCRS multicenter study and identification of risk factors. J. Cataract Refract. Surg. 2007; 33:978-988. [PubMed: 17531690]

Engelbert M, Gilmore MS. Fas ligand but not complement is critical for control of experimental Staphylococcus aureus Endophthalmitis. Invest. Ophthalmol. Vis. Sci. 2005; 46:2479-2486. [PubMed: 15980239]

Engelbert M, Mylonakis E, Ausubel FM, Calderwood SB, Gilmore MS. Contribution of gelatinase, serine protease, and fsr to the pathogenesis of Enterococcus faecalis endophthalmitis. Infect. Immun. 2004; 72:3628-3633. [PubMed: 15155673]

Ermis SS, Cetinkaya Z, Kiyici H, Ozturk F. Treatment of Staphylococcus epidermidis endophthalmitis with intravitreal moxifloxacin in a rabbit model. Tohoku. J. Exp. Med. 2005; 205:223-229. [PubMed: 15718814]

Ermis SS, Cetinkaya Z, Kiyici H, Inan UU, Ozturk F. Effects of intravitreal moxifloxacin and dexamethasone in experimental Staphylococcus aureus endophthalmitis. Curr. Eye Res. 2007; 32:337-344. [PubMed: 17453955]

EVS. Microbiologic factors and visual outcome in the endophthalmitis vitrectomy study. Am. J. Ophthalmol. 1996; 122:830-846. [PubMed: 8956638]

Ferguson AW, Scott JA, McGavigan J, Elton RA, McLean J, Schmidt U, Kelkar R, Dhillon B. Comparison of $5 \%$ povidone-iodine solution against $1 \%$ povidone-iodine solution in preoperative cataract surgery antisepsis: a prospective randomised double blind study. Br. J. Ophthalmol. 2003; 87:163-167. [PubMed: 12543744]

Finks J, Wells E, Dyke TL, Husain N, Plizga L, Heddurshetti R, Wilkins M, Rudrik J, Hageman J, Patel J, Miller C. Vancomycin-resistant Staphylococcus aureus, Michigan, USA, 2007. Emerg. Infect. Dis. 2007; 15:943-945. [PubMed: 19523298]

Friswell M, Campbell B, Rhodes J. The role of bacteria in the pathogenesis of inflammatory bowel disease. Gut Liver. 2010; 4:295-306. [PubMed: 20981205]

Fukuda M, Ohashi H, Matsumoto C, Mishima S, Shimomura Y. Methicillin-resistant Staphylococcus aureus and methicillin-resistant coagulase-negative Staphylococcus ocular surface infection efficacy of chloramphenicol eye drops. Cornea. 2002; 21:S86-S89. [PubMed: 12484705]

Gan IM, Ugahary LC, van Dissel JT, van Meurs JC. Effect of intravitreal dexamethasone on vitreous vancomycin concentrations in patients with suspected postoperative bacterial endophthalmitis. Graefes Arch. Clin. Exp. Ophthalmol. 2005a; 243:1186-1189. [PubMed: 15906066]

Gan IM, Ugahary LC, van Dissel JT, Feron E, Peperkamp E, Veckeneer M, Mulder PG, Platenkamp GJ, van Meurs JC. Intravitreal dexamethasone as adjuvant in the treatment of postoperative endophthalmitis: a prospective randomized trial. Graefes Arch. Clin. Exp. Ophthalmol. 2005b; 243:1200-1205. [PubMed: 16235062]

Garza-Gonzalez E, Lopez D, Pezina C, Muruet W, Bocanegra-Garcia V, Munoz I, Ramirez C, LlacaDiaz JM. Diversity of staphylococcal cassette chromosome mec structures in coagulase-negative staphylococci and relationship to drug resistance. J. Med. Microbiol. 2010; 59:323-329. [PubMed: 20007762]

Prog Retin Eye Res. Author manuscript; available in PMC 2013 July 01. 
Garzozi HJ, Harris A. Intraocular lens implants and risk of endophthalmitis. Br. J. Ophthalmol. 2000; 84:554. [PubMed: 10781525]

Gertz S, Engelmann S, Schmid R, Ziebandt AK, Tischer K, Scharf C, Hacker J, Hecker M. Characterization of the sigma(B) regulon in Staphylococcus aureus. J. Bacteriol. 2000; 182:69836991. [PubMed: 11092859]

Ghelardi E, Celandroni F, Salvetti S, Ceragioli M, Beecher DJ, Senesi S, Wong AC. Swarming behavior of and hemolysin BL secretion by Bacillus cereus. Appl. Environ. Microbiol. 2007; 73:4089-4093. [PubMed: 17449693]

Giacometti A, Cirioni O, Schimizzi AM, Del Prete MS, Barchiesi F, D'Errico MM, Petrelli E, Scalise G. Epidemiology and microbiology of surgical wound infections. J. Clin. Microbiol. 2000; 38:918-922. [PubMed: 10655417]

Giese MJ, Berliner JA, Riesner A, Wagar EA, Mondino BJ. A comparison of the early inflammatory effects of an agr-/sar- versus a wild type strain of Staphylococcus aureus in a rat model of endophthalmitis. Curr. Eye Res. 1999; 18:177-185. [PubMed: 10342372]

Gilmore MS, Haas W. The selective advantage of microbial fratricide. Proc. Natl. Acad. Sci. U. S. A. 2005; 102:8401-8402. [PubMed: 15939890]

Gilmore MS, Cruz-Rodz AL, Leimeister-Wachter M, Kreft J, Goebel W. A Bacillus cereus cytolytic determinant, cereolysin $\mathrm{AB}$, which comprises the phospholipase $\mathrm{C}$ and sphingomyelinase genes: nucleotide sequence and genetic linkage. J. Bacteriol. 1989; 171:744-753. [PubMed: 2536680]

Goerke C, Wolz C. Regulatory and genomic plasticity of Staphylococcus aureus during persistent colonization and infection. Int. J. Med. Microbiol. 2004; 294:195-202. [PubMed: 15493830]

Gotz F. Staphylococcus and biofilms. Mol. Microbiol. 2002; 43:1367-1378. [PubMed: 11952892]

Grandgirard D, Loeffler JM, Fischetti VA, Leib SL. Phage lytic enzyme Cpl-1 for antibacterial therapy in experimental pneumococcal meningitis. J. Infect. Dis. 2008; 197:1519-1522. [PubMed: 18471063]

Guiral S, Mitchell TJ, Martin B, Claverys JP. Competence-programmed predation of non-competent cells in the human pathogen Streptococcus pneumoniae: genetic requirements. Proc. Natl. Acad. Sci. U. S. A. 2005; 102:8710-8715. [PubMed: 15928084]

Gungor SG, Akova YA, Bozkurt A, Yasar U, Babaoglu MO, Cetinkaya A, Colak M. Aqueous humour penetration of moxifloxocin and gatifloxacin eye drops in different dosing regimens before phacoemulsification surgery. Br. J. Ophthalmol. 2011; 95:1272-1275. [PubMed: 21030410]

Guo B, Zhao X, Shi Y, Zhu D, Zhang Y. Pathogenic implication of a fibrinogen-binding protein of Staphylococcus epidermidis in a rat model of intravascular-catheter-associated infection. Infect. Immun. 2007; 75:2991-2995. [PubMed: 17387162]

Haas W, Shepard BD, Gilmore MS. Two-component regulator of Enterococcus faecalis cytolysin responds to quorum-sensing autoinduction. Nature. 2002; 415:84-87. [PubMed: 11780122]

Haas W, Pillar CM, Torres M, Morris TW, Sahm DF. Monitoring Antibiotic Resistance in Ocular Microorganisms: Results from the Antibiotic Resistance Monitoring in Ocular MicRorganisms (ARMOR) 2009 Surveillance Study. Am. J. Ophthalmol. 2011

Hancock LE, Perego M. The Enterococcus faecalis fsr two-component system controls biofilm development through production of gelatinase. J. Bacteriol. 2004; 186:5629-5639. [PubMed: 15317767]

Hartford O, O'Brien L, Schofield K, Wells J, Foster TJ. The Fbe (SdrG) protein of Staphylococcus epidermidis HB promotes bacterial adherence to fibrinogen. Microbiology. 2001; 147:2545-2552. [PubMed: 11535794]

Hashimoto M, Tawaratsumida K, Kariya H, Kiyohara A, Suda Y, Krikae F, Kirikae T, Gotz F. Not lipoteichoic acid but lipoproteins appear to be the dominant immunobiologically active compounds in Staphylococcus aureus. J. Immunol. 2006; 177:3162-3169. [PubMed: 16920954]

Havarstein LS, Coomaraswamy G, Morrison DA. An unmodified heptadecapeptide pheromone induces competence for genetic transformation in Streptococcus pneumoniae. Proc. Natl. Acad. Sci. U. S. A. 1995a; 92:11140-11144. [PubMed: 7479953]

Havarstein LS, Diep DB, Nes IF. A family of bacteriocin ABC transporters carry out proteolytic processing of their substrates concomitant with export. Mol. Microbiol. 1995b; 16:229-240. [PubMed: 7565085] 
Haynes RJ, McElveen JE, Dua HS, Tighe PJ, Liversidge J. Expression of human beta-defensins in intraocular tissues. Invest. Ophthalmol. Vis. Sci. 2000; 41:3026-3031. [PubMed: 10967060]

Heilmann C, Hussain M, Peters G, Gotz F. Evidence for autolysin-mediated primary attachment of Staphylococcus epidermidis to a polystyrene surface. Mol. Microbiol. 1997; 24:1013-1024. [PubMed: 9220008]

Hendriksen WT, Bootsma HJ, Estevao S, Hoogenboezem T, de Jong A, de Groot R, Kuipers OP, Hermans PW. CodY of Streptococcus pneumoniae: link between nutritional gene regulation and colonization. J. Bacteriol. 2008; 190:590-601. [PubMed: 18024519]

Hirst RA, Gosai B, Rutman A, Guerin CJ, Nicotera P, Andrew PW, O'Callaghan C. Streptococcus pneumoniae deficient in pneumolysin or autolysin has reduced virulence in meningitis. J. Infect. Dis. 2008; 197:744-751. [PubMed: 18260758]

Holden MT. Complete genomes of two clinical Staphylococcus aureus strains: evidence for the rapid evolution of virulence and drug resistance. Proc. Natl. Acad. Sci. U. S. A. 2004; 101:9786-9791. [PubMed: 15213324]

Howes EL Jr, Cole PW, Adair TM, Cruse VK, Pollycove M. Cellular and vascular responses in acute experimental ocular inflammation. Invest. Ophthalmol. Vis. Sci. 1994; 35:4031-4038. [PubMed: 7960585]

Huhtinen M, Puolakkainen M, Laasila K, Sarvas M, Karma A, Leirisalo-Repo M. Chlamydial antibodies in patients with previous acute anterior uveitis. Invest. Ophthalmol. Vis. Sci. 2001; 42:1816-1819. [PubMed: 11431447]

Hui FM, Zhou L, Morrison DA. Competence for genetic transformation in Streptococcus pneumoniae: organization of a regulatory locus with homology to two lactococcin A secretion genes. Gene. 1995; 153:25-31. [PubMed: 7883181]

Huntzinger E. Staphylococcus aureus RNA III and the endoribonuclease III coordinately regulate spa gene expression. EMBO J. 2005; 24:824-835. [PubMed: 15678100]

Huseby M, Shi K, Brown CK, Digre J, Mengistu F, Seo KS, Bohach GA, Schlievert PM, Ohlendorf $\mathrm{DH}$, Earhart CA. Structure and biological activities of beta toxin from Staphylococcus aureus. J. Bacteriol. 2007; 189:8719-8726. [PubMed: 17873030]

Jarraud S, Lyon GJ, Figueiredo AM, Gerard L, Vandenesch F, Etienne J, Muir TW, Novick RP. Exfoliatin-producing strains define a fourth agr specificity group in Staphylococcus aureus. J. Bacteriol. 2000; 182:6517-6522. [PubMed: 11053400]

Jefferson KK, Pier DB, Goldmann DA, Pier GB. The teicoplanin-associated locus regulator (TcaR) and the intercellular adhesin locus regulator (IcaR) are transcriptional inhibitors of the ica locus in Staphylococcus aureus. J. Bacteriol. 2004; 186:2449-2456. [PubMed: 15060048]

Jett BD, Jensen HG, Atkuri RV, Gilmore MS. Evaluation of therapeutic measures for treating endophthalmitis caused by isogenic toxin-producing and toxin-nonproducing Enterococcus faecalis strains. Invest. Ophthalmol. Vis. Sci. 1995; 36:9-15. [PubMed: 7822163]

Jevons MP, Coe AW, Parker MT. Methicillin resistance in staphylococci. Lancet. 1963; 1:904-907.

Ji G, Beavis R, Novick RP. Bacterial interference caused by autoinducing peptide variants. Science. 1997; 276:2027-2030. [PubMed: 9197262]

Jonas JB, Knorr HL, Budde WM. Prognostic factors in ocular injuries caused by intraocular or retrobulbar foreign bodies. Ophthalmology. 2000; 107:823-828. [PubMed: 10811069]

Juarez-Verdayes MA, Reyes-Lopez MA, Cancino-Diaz ME, Munoz-Salas S, Rodriguez-Martinez S, de la Serna FJ, Hernandez-Rodriguez CH, Cancino-Diaz JC. Isolation, vancomycin resistance and biofilm production of Staphylococcus epidermidis from patients with conjunctivitis, corneal ulcers, and endophthalmitis. Rev. Latinoam. Microbiol. 2006; 48:238-246. [PubMed: 18293657]

Kanclerski K, Mollby R. Production and purification of Streptococcus pneumoniae hemolysin (pneumolysin). J. Clin. Microbiol. 1987; 25:222-225. [PubMed: 3818918]

Katayama Y, Ito T, Hiramatsu K. A new class of genetic element, staphylococcus cassette chromosome mecencodes methicillin resistance in Staphylococcus aureus. Antimicrob. Agents Chemother. 2000; 44:1549-1555. [PubMed: 10817707]

Kattan HM, Flynn HW Jr, Pflugfelder SC, Robertson C, Forster RK. Nosocomial endophthalmitis survey. Current incidence of infection after intraocular surgery. Ophthalmology. 1991; 98:227238. [PubMed: 2008282] 
Kazakova SV. A clone of methicillin-resistant Staphylococcus aureus among professional football players. N. Engl. J. Med. 2005; 352:468-475. [PubMed: 15689585]

Kim SJ, Toma HS. Antimicrobial resistance and ophthalmic antibiotics: 1-year results of a longitudinal controlled study of patients undergoing intravitreal injections. Arch. Ophthalmol. 2011; 129:1180-1188. [PubMed: 21911665]

Kinnebrew MA, Ubeda C, Zenewicz LA, Smith N, Flavell RA, Pamer EG. Bacterial flagellin stimulates Toll-like receptor 5-dependent defense against vancomycin-resistant Enterococcus infection. J. Infect. Dis. 2010; 201:534-543. [PubMed: 20064069]

Klein KS, Walsh MK, Hassan TS, Halperin LS, Castellarin AA, Roth D, Driscoll S, Prenner JL. Endophthalmitis after anti-VEGF injections. Ophthalmology. 2009; 116:1225.e1. [PubMed: 19486799]

Klevens RM. Invasive methicillin-resistant Staphylococcus aureus infections in the United States. JAMA. 2007; 298:1763-1771. [PubMed: 17940231]

Kobayakawa S, Jett BD, Gilmore MS. Biofilm formation by Enterococcus faecalis on intraocular lens material. Curr Eye Res. 2005; 30:741-745. [PubMed: 16146919]

Kodjikian L, Couprie J, Hachicha W, Timour Q, Devouassoux M, Builles N, Hartmann D, Fessi H. Experimental Intracameral Injection Of Vancomycin Micro particles In Rabbits. Invest. Ophthalmol. Vis. Sci. 2010

Koizumi K, Poulaki V, Doehmen S, Welsandt G, Radetzky S, Lappas A, Kociok N, Kirchhof B, Joussen AM. Contribution of TNF-alpha to leukocyte adhesion, vascular leakage, and apoptotic cell death in endotoxin-induced uveitis in vivo. Invest. Ophthalmol. Vis. Sci. 2003; 44:21842191. [PubMed: 12714660]

Kong KF, Vuong C, Otto M. Staphylococcus quorum sensing in biofilm formation and infection. Int. J. Med. Microbiol. 2006; 296:133-139. [PubMed: 16487744]

Krivan HC, Roberts DD, Ginsburg V. Many pulmonary pathogenic bacteria bind specifically to the carbohydrate sequence GalNAc beta $1-4 \mathrm{Gal}$ found in some glycolipids. Proc. Natl. Acad. Sci. U. S. A. 1988; 85:6157-6161. [PubMed: 3413084]

Kullik I, Giachino P, Fuchs T. Deletion of the alternative sigma factor sigmaB in Staphylococcus aureus reveals its function as a global regulator of virulence genes. J. Bacteriol. 1998; 180:48144820. [PubMed: 9733682]

Lalwani GA, Flynn HW Jr, Scott IU, Quinn CM, Berrocal AM, Davis JL, Murray TG, Smiddy WE, Miller D. Acute-onset endophthalmitis after clear corneal cataract surgery (1996-2005). Clinical features, causative organisms, and visual acuity outcomes. Ophthalmology. 2008; 115:473-476. [PubMed: 18067969]

Lamont M, Booth A. Post-traumatic endophthalmitis following penetrating injury with dental needle. Eye (Lond). 2006; 20:981-982. [PubMed: 16179935]

Leng T, Miller D, Flynn HW Jr, Jacobs DJ, Gedde SJ. Delayed-onset bleb-associated endophthalmitis (1996-2008): causative organisms and visual acuity outcomes. Retina. 2011; 31:344-352. [PubMed: 20838358]

Lerner LE, Polansky JR, Howes EL, Stern R. Hyaluronan in the human trabecular meshwork. Invest. Ophthalmol. Vis. Sci. 1997; 38:1222-1228. [PubMed: 9152242]

Liu C. Clinical practice guidelines by the infectious diseases society of america for the treatment of methicillin-resistant Staphylococcus aureus infections in adults and children. Clin. Infect. Dis. 2011; 52:e18-e55. [PubMed: 21208910]

Liu F, Kwok AK, Cheung BM. The efficacy of intravitreal vancomycin and dexamethasone in the treatment of experimental bacillus cereus endophthalmitis. Curr. Eye Res. 2008; 33:761-768. [PubMed: 18798079]

Mac I, Soltau JB. Glaucoma-filtering bleb infections. Curr. Opin. Ophthalmol. 2003; 14:91-94. [PubMed: 12698049]

Majerczyk CD, Sadykov MR, Luong TT, Lee C, Somerville GA, Sonenshein AL. Staphylococcus aureus CodY negatively regulates virulence gene expression. J. Bacteriol. 2008; 190:2257-2265. [PubMed: 18156263] 
Majerczyk CD, Dunman PM, Luong TT, Lee CY, Sadykov MR, Somerville GA, Bodi K, Sonenshein AL. Direct targets of CodY in Staphylococcus aureus. J. Bacteriol. 2010; 192:2861-2877. [PubMed: 20363936]

Major JC Jr, Engelbert M, Flynn HW Jr, Miller D, Smiddy WE, Davis JL. Staphylococcus aureus endophthalmitis: antibiotic susceptibilities, methicillin resistance, and clinical outcomes. Am. J. Ophthalmol. 2010; 149:278-283. e1. [PubMed: 19926069]

Manna A, Cheung AL. Characterization of sarR, a modulator of sar expression in Staphylococcus aureus. Infect. Immun. 2001; 69:885-896. [PubMed: 11159982]

Mao LK, Flynn HW Jr, Miller D, Pflugfelder SC. Endophthalmitis caused by streptococcal species. Arch. Ophthalmol. 1992; 110:798-801. [PubMed: 1596227]

Marshall MJ, Bohach GA, Boehm DF. Characterization of Staphylococcus aureus beta-toxin induced leukotoxicity. J. Nat. Toxins. 2000; 9:125-138. [PubMed: 10868340]

McMenamin PG, Crewe J, Morrison S, Holt PG. Immunomorphologic studies of macrophages and MHC class II-positive dendritic cells in the iris and ciliary body of the rat, mouse, and human eye. Invest. Ophthalmol. Vis. Sci. 1994; 35:3234-3250. [PubMed: 8045716]

Meredith TA, Aguilar HE, Drews C, Sawant A, Gardner S, Wilson LA, Grossniklaus HE. Intraocular dexamethasone produces a harmful effect on treatment of experimental Staphylococcus aureus endophthalmitis. Trans. Am. Ophthalmol. Soc. 1996; 94:241-252. discussion 252-7. [PubMed: 8981699]

Miller D, Flynn PM, Scott IU, Alfonso EC, Flynn HW Jr. In vitro fluoroquinolone resistance in staphylococcal endophthalmitis isolates. Arch. Ophthalmol. 2006; 124:479-483. [PubMed: 16606872]

Miller DM, Vedula AS, Flynn HW Jr, Miller D, Scott IU, Smiddy WE, Murray TG, Venkatraman AS. Endophthalmitis caused by staphylococcus epidermidis: in vitro antibiotic susceptibilities and clinical outcomes. Ophthalmic Surg. Lasers Imaging. 2007; 38:446-451. [PubMed: 18050805]

Miller JJ, Scott IU, Flynn HW Jr, Smiddy WE, Newton J, Miller D. Acute-onset endophthalmitis after cataract surgery (2000-2004): incidence, clinical settings, and visual acuity outcomes after treatment. Am. J. Ophthalmol. 2005; 139:983-987. [PubMed: 15953426]

Mino de Kaspar H, Chang RT, Singh K, Egbert PR, Blumenkranz MS, Ta CN. Prospective randomized comparison of 2 different methods of $5 \%$ povidone-iodine applications for anterior segment intraocular surgery. Arch. Ophthalmol. 2005; 123:161-165. [PubMed: 15710810]

Miragaia M. Genetic diversity of arginine catabolic mobile element in Staphylococcus epidermidis. PLoS One. 2009; 4:e7722. [PubMed: 19893740]

Montan PG, Wejde G, Koranyi G, Rylander M. Prophylactic intracameral cefuroxime. Efficacy in preventing endophthalmitis after cataract surgery. J. Cataract Refract. Surg. 2002; 28:977-981. [PubMed: 12036639]

Moreillon P, Entenza JM, Francioli P, McDevitt D, Foster TJ, Francois P, Vaudaux P. Role of Staphylococcus aureus coagulase and clumping factor in pathogenesis of experimental endocarditis. Infect. Immun. 1995; 63:4738-4743. [PubMed: 7591130]

Morfeldt E, Janzon L, Arvidson S, Lofdahl S. Cloning of a chromosomal locus (exp) which regulates the expression of several exoprotein genes in Staphylococcus aureus. Mol. Gen. Genet. 1988; 211:435-440. [PubMed: 3285138]

Morfeldt E, Taylor D, von Gabain A, Arvidson S. Activation of alpha-toxin translation in Staphylococcus aureus by the trans-encoded antisense RNA, RNA III. EMBO J. 1995; 14:45694577. [PubMed: 7556100]

Moss JM, Sanislo SR, Ta CN. A prospective randomized evaluation of topical gatifloxacin on conjunctival flora in patients undergoing intravitreal injections. Ophthalmology. 2009; 116:1498-1501. [PubMed: 19501409]

Moyer AL, Ramadan RT, Thurman J, Burroughs A, Callegan MC. Bacillus cereus induces permeability of an in vitro blood-retina barrier. Infect. Immun. 2008; 76:1358-1367. [PubMed: 18268029]

Moyer AL, Ramadan RT, Novosad BD, Astley R, Callegan MC. Bacillus cereus-induced permeability of the blood-ocular barrier during experimental endophthalmitis. Invest. Ophthalmol. Vis. Sci. 2009; 50:3783-3793. [PubMed: 19264886] 
Murata M, Horiuchi S. Hyaluronan synthases, hyaluronan and its CD44 receptors in the posterior segment of rabbit eye. Ophthalmologica. 2005; 219:287-291. [PubMed: 16123555]

Murjaneh S, Waqar S, Hale JE, Kasmiya M, Jacob J, Quinn AG. National survey of the use of intraoperative antibiotics for prophylaxis against postoperative endophthalmitis following cataract surgery in the UK. Br. J. Ophthalmol. 2010; 94:1410-1411. [PubMed: 20710049]

Murray BE. Vancomycin-resistant enterococcal infections. N. Engl. J. Med. 2000; 342:710-721. [PubMed: 10706902]

Nakayama J, Cao Y, Horii T, Sakuda S, Akkermans AD, de Vos WM, Nagasawa H. Gelatinase biosynthesis-activating pheromone: a peptide lactone that mediates a quorum sensing in Enterococcus faecalis. Mol. Microbiol. 2001; 41:145-154. [PubMed: 11454207]

Nakayama J, Chen S, Oyama N, Nishiguchi K, Azab EA, Tanaka E, Kariyama R, Sonomoto K. Revised model for Enterococcus faecalis fsr quorum-sensing system: the small open reading frame fsrD encodes the gelatinase biosynthesis-activating pheromone propeptide corresponding to staphylococcal agrd. J. Bacteriol. 2006; 188:8321-8326. [PubMed: 16980448]

Nayak N. Fungal infections of the eye--laboratory diagnosis and treatment. Nepal Med. Coll. J. 2008; 10:48-63. [PubMed: 18700633]

Ng EW, Costa JR, Samiy N, Ruoff KL, Connolly E, Cousins FV, D'Amico DJ. Contribution of pneumolysin and autolysin to the pathogenesis of experimental pneumococcal endophthalmitis. Retina. 2002; 22:622-632. [PubMed: 12441729]

Nilsson M, Frykberg L, Flock JI, Pei L, Lindberg M, Guss B. A fibrinogen-binding protein of Staphylococcus epidermidis. Infect. Immun. 1998; 66:2666-2673. [PubMed: 9596732]

Novick RP. Autoinduction and signal transduction in the regulation of staphylococcal virulence. Mol. Microbiol. 2003; 48:1429-1449. [PubMed: 12791129]

Ong-Tone L. Aqueous humor penetration of gatifloxacin and moxifloxacin eye drops given by different methods before cataract surgery. J. Cataract Refract. Surg. 2007; 33:59-62. [PubMed: 17189794]

Orihuela CJ, Mahdavi J, Thornton J, Mann B, Wooldridge KG, Abouseada N, Oldfield NJ, Self T, Ala'Aldeen DA, Tuomanen EI. Laminin receptor initiates bacterial contact with the blood brain barrier in experimental meningitis models. J. Clin. Invest. 2009; 119:1638-1646. [PubMed: 19436113]

Ormerod LD, Becker LE, Cruise RJ, Grohar HI, Paton BG, Frederick AR Jr, Topping TM, Weiter JJ, Buzney SM, Baker AS. Endophthalmitis caused by the coagulase-negative staphylococci. 2. Factors influencing presentation after cataract surgery. Ophthalmology. 1993; 100:724-729. [PubMed: 8493016]

Otto M. Staphylococcus epidermidis--the 'accidental' pathogen. Nat. Rev. Microbiol. 2009; 7:555-567. [PubMed: 19609257]

Otto M, Sussmuth R, Vuong C, Jung G, Gotz F. Inhibition of virulence factor expression in Staphylococcus aureus by the Staphylococcus epidermidis agr pheromone and derivatives. FEBS Lett. 1999; 450:257-262. [PubMed: 10359085]

Palmqvist N, Patti JM, Tarkowski A, Josefsson E. Expression of staphylococcal clumping factor A impedes macrophage phagocytosis. Microbes Infect. 2004; 6:188-195. [PubMed: 14998517]

Parmar P, Salman A, Kaliamurthy J, Prasanth DA, Thomas PA, Jesudasan CA. Anterior chamber contamination during phacoemulsification and manual small-incision cataract surgery. Am. J. Ophthalmol. 2006; 141:1160-1161. [PubMed: 16765701]

Pastagia M, Euler C, Chahales P, Fuentes-Duculan J, Krueger JG, Fischetti VA. A novel chimeric lysin shows superiority to mupirocin for skin decolonization of methicillin-resistant and sensitive Staphylococcus aureus strains. Antimicrob. Agents Chemother. 2011; 55:738-744. [PubMed: 21098252]

Patel AH, Nowlan P, Weavers ED, Foster T. Virulence of protein A-deficient and alpha-toxindeficient mutants of Staphylococcus aureus isolated by allele replacement. Infect. Immun. 1987; 55:3103-3110. [PubMed: 3679545]

Paton JC, Ferrante A. Inhibition of human polymorphonuclear leukocyte respiratory burst, bactericidal activity, and migration by pneumolysin. Infect. Immun. 1983; 41:1212-1216. [PubMed: 6885160] 
Paton JC, Berry AM, Lock RA. Molecular analysis of putative pneumococcal virulence proteins. Microb. Drug Resist. 1997; 3:1-10. [PubMed: 9109091]

Pelz A, Wieland KP, Putzbach K, Hentschel P, Albert K, Gotz F. Structure and biosynthesis of staphyloxanthin from Staphylococcus aureus. J. Biol. Chem. 2005; 280:32493-32498. [PubMed: 16020541]

Peng YJ, Kau YC, Wen CW, Liu KS, Liu SJ. Solvent-free biodegradable scleral plugs providing sustained release of vancomycin, amikacin, and dexamethasone--an in vivo study. J. Biomed. Mater. Res. A. 2010; 94:426-432. [PubMed: 20186737]

Pestova EV, Havarstein LS, Morrison DA. Regulation of competence for genetic transformation in Streptococcus pneumoniae by an auto-induced peptide pheromone and a two-component regulatory system. Mol. Microbiol. 1996; 21:853-862. [PubMed: 8878046]

Petropoulos IK, Vantzou CV, Lamari FN, Karamanos NK, Anastassiou ED, Pharmakakis NM. Expression of TNF-alpha, IL-1beta, and IFN-gamma in Staphylococcus epidermidis slimepositive experimental endophthalmitis is closely related to clinical inflammatory scores. Graefes Arch. Clin. Exp. Ophthalmol. 2006; 244:1322-1328. [PubMed: 16544114]

Peyman GA, Lad EM, Moshfeghi DM. Intravitreal injection of therapeutic agents. Retina. 2009; 29:875-912. [PubMed: 19584648]

Pierre DJ, Tang J. Bleb associated endophthalmitis with methicillin-resistant Staphylococcus aureus. Br. J. Ophthalmol. 2010; 94:390-392. [PubMed: 20215385]

Pijl BJ, Theelen T, Tilanus MA, Rentenaar R, Crama N. Acute endophthalmitis after cataract surgery: 250 consecutive cases treated at a tertiary referral center in the Netherlands. Am. J. Ophthalmol. 2010; 149:482-487. e1-2. [PubMed: 20053391]

Pohl K, Francois P, Stenz L, Schlink F, Geiger T, Herbert S, Goerke C, Schrenzel J, Wolz C. CodY in Staphylococcus aureus: a regulatory link between metabolism and virulence gene expression. J. Bacteriol. 2009; 191:2953-2963. [PubMed: 19251851]

Postma B, Poppelier MJ, van Galen JC, Prossnitz ER, van Strijp JA, de Haas CJ, van Kessel KP. Chemotaxis inhibitory protein of Staphylococcus aureus binds specifically to the C5a and formylated peptide receptor. J. Immunol. 2004; 172:6994-7001. [PubMed: 15153520]

Qin X, Singh KV, Weinstock GM, Murray BE. Effects of Enterococcus faecalis fsr genes on production of gelatinase and a serine protease and virulence. Infect. Immun. 2000; 68:25792586. [PubMed: 10768947]

Raad I, Alrahwan A, Rolston K. Staphylococcus epidermidis: emerging resistance and need for alternative agents. Clin. Infect. Dis. 1998; 26:1182-1187. [PubMed: 9597250]

Ramadan RT, Moyer AL, Callegan MC. A role for tumor necrosis factor-alpha in experimental Bacillus cereus endophthalmitis pathogenesis. Invest. Ophthalmol. Vis. Sci. 2008; 49:44824489. [PubMed: 18586878]

Ramadan RT, Ramirez R, Novosad BD, Callegan MC. Acute inflammation and loss of retinal architecture and function during experimental Bacillus endophthalmitis. Curr. Eye Res. 2006; 31:955-965. [PubMed: 17114121]

Rechtin TM, Gillaspy AF, Schumacher MA, Brennan RG, Smeltzer MS, Hurlburt BK. Characterization of the SarA virulence gene regulator of Staphylococcus aureus. Mol. Microbiol. 1999; 33:307-316. [PubMed: 10411747]

Romero P, Mendez I, Salvat M, Fernandez J, Almena M. Intracameral cefazolin as prophylaxis against endophthalmitis in cataract surgery. J. Cataract Refract Surg. 2006; 32:438-441. [PubMed: 16631053]

Rosen SD. Ligands for L-selectin: homing, inflammation, and beyond. Annu. Rev. Immunol. 2004; 22:129-156. [PubMed: 15032576]

Rosenfeld PJ, Brown DM, Heier JS, Boyer DS, Kaiser PK, Chung CY, Kim RY. MARINA Study Group. Ranibizumab for neovascular age-related macular degeneration. N. Engl. J. Med. 2006; 355:1419-1431. [PubMed: 17021318]

Sampat KM, Garg SJ. Complications of intravitreal injections. Curr. Opin. Ophthalmol. 2010; 21:178183. [PubMed: 20375895]

Schmidt KA, Manna AC, Gill S, Cheung AL. SarT, a repressor of alpha-hemolysin in Staphylococcus aureus. Infect. Immun. 2001; 69:4749-4758. [PubMed: 11447147] 
Seles S, Lang GE. Ocular manifestation of an infectious endocarditis. Klin. Monbl Augenheilkd. 2007; 224:606-608. [PubMed: 17657697]

Shah GK, Stein JD, Sharma S, Sivalingam A, Benson WE, Regillo CD, Brown GC, Tasman W. Visual outcomes following the use of intravitreal steroids in the treatment of postoperative endophthalmitis. Ophthalmology. 2000; 107:486-489. [PubMed: 10711885]

Shamsuddin N, Kumar A. TLR2 mediates the innate response of retinal Muller glia to Staphylococcus aureus. J. Immunol. 2011; 186:7089-7097. [PubMed: 21602496]

Shankar N, Coburn P, Pillar C, Haas W, Gilmore M. Enterococcal cytolysin: activities and association with other virulence traits in a pathogenicity island. Int. J. Med. Microbiol. 2004; 293:609-618. [PubMed: 15149038]

Sharifi E, Porco TC, Naseri A. Cost-effectiveness analysis of intracameral cefuroxime use for prophylaxis of endophthalmitis after cataract surgery. Ophthalmology. 2009; 116:1887-1896. e1. [PubMed: 19560825]

Shirodkar AR, Flynn HW, Alliman K, Lalwani GA, Alabiad C, Moshfeghi AA, Miller D. The comparison of clinical outcomes of endophthalmitis from fluoroquinolone-resistant and susceptible bacteria. Clin. Ophthalmol. 2010; 4:211-214. [PubMed: 20463786]

Singh KP, Shau H, Gupta RK, Kopald K, Ray PK. Protein A potentiates lymphokine-activated killer cell induction in normal and melanoma patient lymphocytes. Immunopharmacol. Immunotoxicol. 1992; 14:73-103. [PubMed: 1597662]

Sinha P, Ghosh AK, Das T, Sa G, Ray PK. Protein A of Staphylococcus aureus evokes Th1 type response in mice. Immunol. Lett. 1999; 67:157-165. [PubMed: 10369122]

Slamti L, Lereclus D. A cell-cell signaling peptide activates the PlcR virulence regulon in bacteria of the Bacillus cereus group. EMBO. J. 2002; 21:4550-4559. [PubMed: 12198157]

Smith MA, Sorenson JA, Smith C, Miller M, Borenstein M. Effects of intravitreal dexamethasone on concentration of intravitreal vancomycin in experimental methicillin-resistant Staphylococcus epidermidis endophthalmitis. Antimicrob. Agents Chemother. 1991; 35:1298-1302. [PubMed: 1929285]

Smith SR, Kroll AJ, Lou PL, Ryan EA. Endogenous bacterial and fungal endophthalmitis. Int. Ophthalmol. Clin. 2007; 47:173-183. [PubMed: 17450017]

Sonenshein AL. CodY, a global regulator of stationary phase and virulence in Gram-positive bacteria. Curr. Opin. Microbiol. 2005; 8:203-207. [PubMed: 15802253]

Sonenshein AL. Control of key metabolic intersections in Bacillus subtilis. Nat. Rev. Microbiol. 2007; 5:917-927. [PubMed: 17982469]

Song Z, Marzilli L, Greenlee BM, Chen ES, Silver RF, Askin FB, Teirstein AS, Zhang Y, Cotter RJ, Moller DR. Mycobacterial catalase-peroxidase is a tissue antigen and target of the adaptive immune response in systemic sarcoidosis. J. Exp. Med. 2005; 201:755-767. [PubMed: 15753209]

Speaker MG, Menikoff JA. Prophylaxis of endophthalmitis with topical povidone-iodine. Ophthalmology. 1991; 98:1769-1775. [PubMed: 1775308]

Streilein JW. Ocular immune privilege: therapeutic opportunities from an experiment of nature. Nat. Rev. Immunol. 2003; 3:879-889. [PubMed: 14668804]

Strober W. Inside the microbial and immune labyrinth: Gut microbes: friends or fiends? Nat. Med. 2010; 16:1195-1197. [PubMed: 21052070]

Suzuki T, Campbell J, Swoboda JG, Walker S, Gilmore MS. Role of wall teichoic acids in Staphylococcus aureus endophthalmitis. Invest. Ophthalmol. Vis. Sci. 2011; 52:3187-3192. [PubMed: 21345983]

Suzuki T, Wada T, Kozai S, Ike Y, Gilmore MS, Ohashi Y. Contribution of secreted proteases to the pathogenesis of postoperative Enterococcus faecalis endophthalmitis. J. Cataract Refract. Surg. 2008; 34:1776-1784. [PubMed: 18812133]

Taban M, Behrens A, Newcomb RL, Nobe MY, Saedi G, Sweet PM, McDonnell PJ. Acute endophthalmitis following cataract surgery: a systematic review of the literature. Arch. Ophthalmol. 2005; 123:613-620. [PubMed: 15883279]

Tang CW, Cheng CK, Lee TS. Community-acquired bleb-related endophthalmitis caused by vancomycin-resistant enterococci. Can. J. Ophthalmol. 2007; 42:477-478. [PubMed: 17508051] 
Taylor AW. The immunomodulating neuropeptide alpha-melanocyte-stimulating hormone (alphaMSH) suppresses LPS-stimulated TLR4 with IRAK-M in macrophages. J. Neuroimmunol. 2005; 162:43-50. [PubMed: 15833358]

Taylor AW. Ocular immune privilege. Eye (Lond). 2009; 23:1885-1889. [PubMed: 19136922]

Taylor AW, Streilein JW, Cousins SW. Identification of alpha-melanocyte stimulating hormone as a potential immunosuppressive factor in aqueous humor. Curr. Eye Res. 1992; 11:1199-1206. [PubMed: 1490338]

Tegmark K, Karlsson A, Arvidson S. Identification and characterization of SarH1, a new global regulator of virulence gene expression in Staphylococcus aureus. Mol. Microbiol. 2000; 37:398409. [PubMed: 10931334]

Tenover FC, McDougal LK, Goering RV, Killgore G, Projan SJ, Patel JB, Dunman PM. Characterization of a strain of community-associated methicillin-resistant Staphylococcus aureus widely disseminated in the United States. J. Clin. Microbiol. 2006; 44:108-118. [PubMed: 16390957]

Thomas VC, Thurlow LR, Boyle D, Hancock LE. Regulation of autolysis-dependent extracellular DNA release by Enterococcus faecalis extracellular proteases influences biofilm development. J. Bacteriol. 2008; 190:5690-5698. [PubMed: 18556793]

Thompson JT, Parver LM, Enger CL, Mieler WF, Liggett PE. Infectious endophthalmitis after penetrating injuries with retained intraocular foreign bodies. National Eye Trauma System. Ophthalmology. 1993; 100:1468-1474. [PubMed: 8414406]

Thompson WS, Rubsamen PE, Flynn HW Jr, Schiffman J, Cousins SW. Endophthalmitis after penetrating trauma. Risk factors and visual acuity outcomes. Ophthalmology. 1995; 102:16961701. [PubMed: 9098264]

Thurlow LR, Thomas VC, Narayanan S, Olson S, Fleming SD, Hancock LE. Gelatinase contributes to the pathogenesis of endocarditis caused by Enterococcus faecalis. Infect. Immun. 2010; 78:49364943. [PubMed: 20713628]

Timmerman CP, Mattsson E, Martinez-Martinez L, De Graaf L, Van Strijp JA, Verbrugh HA, Verhoef J, Fleer A. Induction of release of tumor necrosis factor from human monocytes by staphylococci and staphylococcal peptidoglycans. Infect. Immun. 1993; 61:4167-4172. [PubMed: 8406805]

Tweten RK. Cholesterol-dependent cytolysins, a family of versatile pore-forming toxins. Infect. Immun. 2005; 73:6199-6209. [PubMed: 16177291]

Uchiyama S, Carlin AF, Khosravi A, Weiman S, Banerjee A, Quach D, Hightower G, Mitchell TJ, Doran KS, Nizet V. The surface-anchored NanA protein promotes pneumococcal brain endothelial cell invasion. J. Exp. Med. 2009; 206:1845-1852. [PubMed: 19687228]

Van de Beek D. Corticosteroids for acute adult bacterial meningitis. Med. Mal. Infect. 2009; 39:531538. [PubMed: 19386456]

Vandersteegen K. Microbiological and Molecular Assessment of Bacteriophage ISP for the Control of Staphylococcus aureus. PLoS One. 2011; 6:e24418. [PubMed: 21931710]

D'Amico DJ, Masonson HN, Patel M, Adamis AP, Cunningham ET Jr, Guyer DR, Katz B. VEGF Inhibition Study in Ocular Neovascularization (V.I.S.I.O.N.) Clinical Trial Group. Pegaptanib sodium for neovascular age-related macular degeneration: two-year safety results of the two prospective, multicenter, controlled clinical trials. Ophthalmology. 2006; 113:992-1001. e6. [PubMed: 16647134]

Villari P, Sarnataro C, Iacuzio L. Molecular epidemiology of Staphylococcus epidermidis in a neonatal intensive care unit over a three-year period. J. Clin. Microbiol. 2000; 38:1740-1746. [PubMed: 10790091]

Vuong C, Saenz HL, Gotz F, Otto M. Impact of the agr quorum-sensing system on adherence to polystyrene in Staphylococcus aureus. J. Infect. Dis. 2000; 182:1688-1693. [PubMed: 11069241]

Vuong C, Durr M, Carmody AB, Peschel A, Klebanoff SJ, Otto M. Regulated expression of pathogenassociated molecular pattern molecules in Staphylococcus epidermidis: quorum-sensing determines pro-inflammatory capacity and production of phenol-soluble modulins. Cell. Microbiol. 2004; 6:753-759. [PubMed: 15236642] 
Wakefield D, Stahlberg TH, Toivanen A, Granfors K, Tennant C. Serologic evidence of Yersinia infection in patients with anterior uveitis. Arch. Ophthalmol. 1990; 108:219-221. [PubMed: 2302105]

Walev I, Martin E, Jonas D, Mohamadzadeh M, Muller-Klieser W, Kunz L, Bhakdi S. Staphylococcal alpha-toxin kills human keratinocytes by permeabilizing the plasma membrane for monovalent ions. Infect. Immun. 1993; 61:4972-4979. [PubMed: 8225571]

Wang R. Identification of novel cytolytic peptides as key virulence determinants for communityassociated MRSA. Nat. Med. 2007; 13:1510-1514. [PubMed: 17994102]

Wejde G, Montan P, Lundstrom M, Stenevi U, Thorburn W. Endophthalmitis following cataract surgery in Sweden: national prospective survey 1999-2001. Acta Ophthalmol. Scand. 2005; 83:7-10. [PubMed: 15715550]

West ES, Behrens A, McDonnell PJ, Tielsch JM, Schein OD. The incidence of endophthalmitis after cataract surgery among the U.S. Medicare population increased between 1994 and 2001. Ophthalmology. 2005; 112:1388-1394. [PubMed: 15953637]

Whiston EA, Sugi N, Kamradt MC, Sack C, Heimer SR, Engelbert M, Wawrousek EF, Gilmore MS, Ksander BR, Gregory MS. alphaB-crystallin protects retinal tissue during Staphylococcus aureus-induced endophthalmitis. Infect. Immun. 2008; 76:1781-1790. [PubMed: 18227158]

Wiskur BJ, Robinson ML, Farrand AJ, Novosad BD, Callegan MC. Toward improving therapeutic regimens for Bacillus endophthalmitis. Invest. Ophthalmol. Vis. Sci. 2008; 49:1480-1487. [PubMed: 18385066]

Witzenrath M. Systemic use of the endolysin Cpl-1 rescues mice with fatal pneumococcal pneumonia. Crit. Care Med. 2009; 37:642-649. [PubMed: 19114881]

Wright JS 3rd, Jin R, Novick RP. Transient interference with staphylococcal quorum sensing blocks abscess formation. Proc. Natl. Acad. Sci. U. S. A. 2005; 102:1691-1696. [PubMed: 15665088]

Wu PC, Li M, Chang SJ, Teng MC, Yow SG, Shin SJ, Kuo HK. Risk of endophthalmitis after cataract surgery using different protocols for povidone-iodine preoperative disinfection. J. Ocul. Pharmacol. Ther. 2006; 22:54-61. [PubMed: 16503776]

Wykoff CC, Parrott MB, Flynn HW Jr, Shi W, Miller D, Alfonso EC. Nosocomial acute-onset postoperative endophthalmitis at a university teaching hospital (2002-2009). Am. J. Ophthalmol. 2010; 150:392.e2-398.e2. [PubMed: 20619391]

$\mathrm{Xu} \mathrm{KD}, \mathrm{McF}$ eters GA, Stewart PS. Biofilm resistance to antimicrobial agents. Microbiology. 2000; 146(Pt 3):547-549. [PubMed: 10746758]

Yanagihori H, Oyama N, Nakamura K, Mizuki N, Oguma K, Kaneko F. Role of IL-12B promoter polymorphism in Adamantiades-Behcet's disease susceptibility: An involvement of Th1 immunoreactivity against Streptococcus Sanguinis antigen. J. Invest. Dermatol. 2006; 126:15341540. [PubMed: 16514412]

Yarwood JM, Bartels DJ, Volper EM, Greenberg EP. Quorum sensing in Staphylococcus aureus biofilms. J. Bacteriol. 2004; 186:1838-1850. [PubMed: 14996815]

Yildirim O, Oz O, Aslan G, Cinel L, Delialioglu N, Kanik A. The efficacy of intravitreal levofloxacin and intravitreal dexamethasone in experimental Staphylococcus epidermidis endophthalmitis. Ophthalmic Res. 2002; 34:349-356. [PubMed: 12483022]

Yoshida J, Kim A, Pratzer KA, Stark WJ. Aqueous penetration of moxifloxacin $0.5 \%$ ophthalmic solution and besifloxacin $0.6 \%$ ophthalmic suspension in cataract surgery patients. J. Cataract Refract. Surg. 2010; 36:1499-1502. [PubMed: 20692561]

Yu-Wai-Man P, Morgan SJ, Hildreth AJ, Steel DH, Allen D. Efficacy of intracameral and subconjunctival cefuroxime in preventing endophthalmitis after cataract surgery. J. Cataract Refract. Surg. 2008; 34:447-451. [PubMed: 18299070]

Zetola N, Francis JS, Nuermberger EL, Bishai WR. Community-acquired meticillin-resistant Staphylococcus aureus: an emerging threat. Lancet Infect. Dis. 2005; 5:275-286. [PubMed: 15854883]

Zhang K, McClure JA, Elsayed S, Conly JM. Novel staphylococcal cassette chromosome mec type, tentatively designated type VIII, harboring class A mec and type 4 ccr gene complexes in a Canadian epidemic strain of methicillin-resistant Staphylococcus aureus. Antimicrob. Agents Chemother. 2009; 53:531-540. [PubMed: 19064897] 


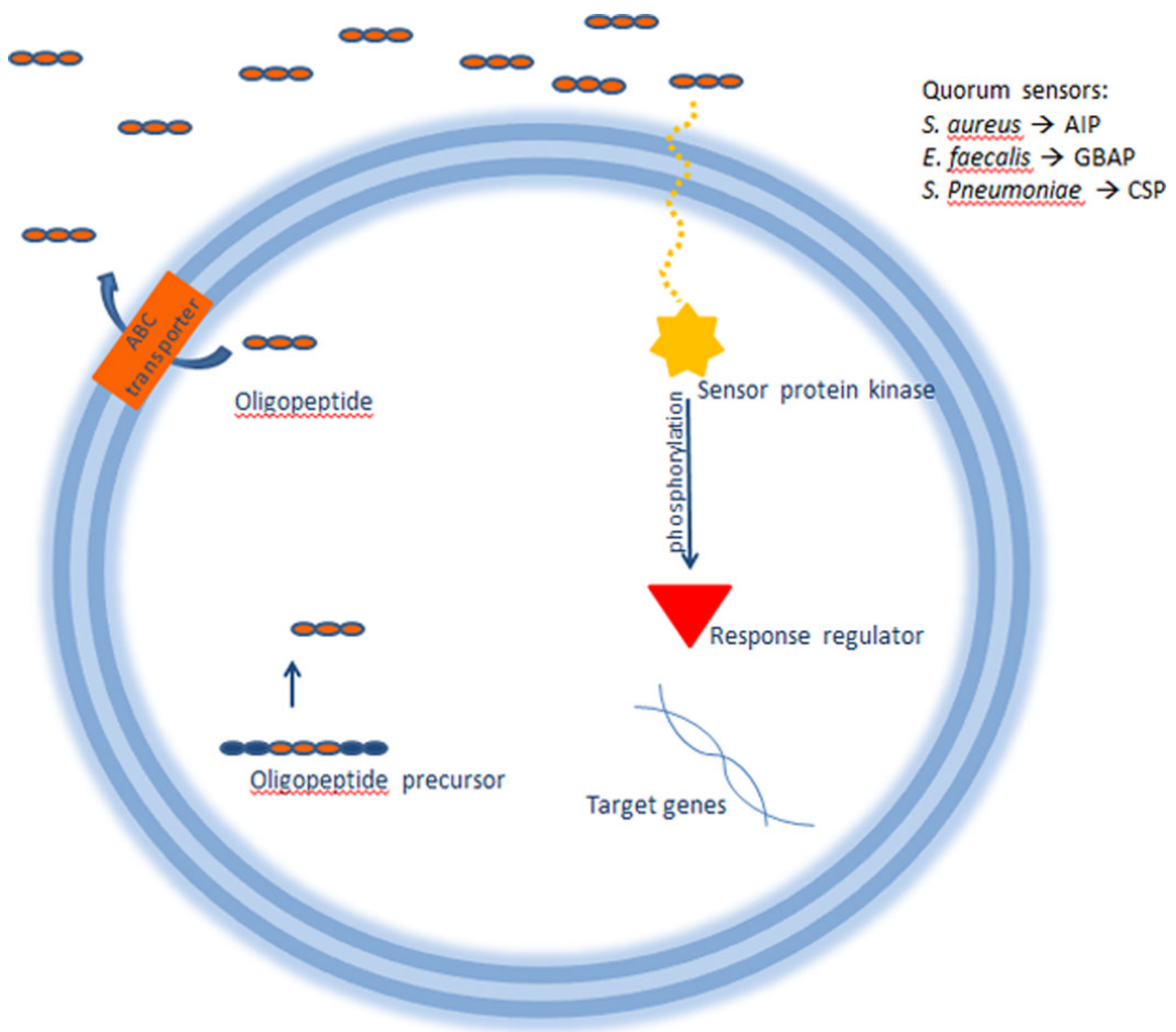

Figure 1.

Peptide-based quorum sensing in gram positive bacteria. A precursor peptide cosecretionally processed into mature form by an $\mathrm{ABC}$ transporter. The peptide accumulates outside the cell as function of bacterial cell density. A threshold level detected by the cognate sensor histidine protein kinase transduces the signal to a response regulator through phosphotransfer. This leads to a shift in global regulation of virulence gene expression. Competence-stimulating peptide (CSP); gelatinase biosynthesis-activating pheromone (GBAP); auto inducing peptide (AIP). 


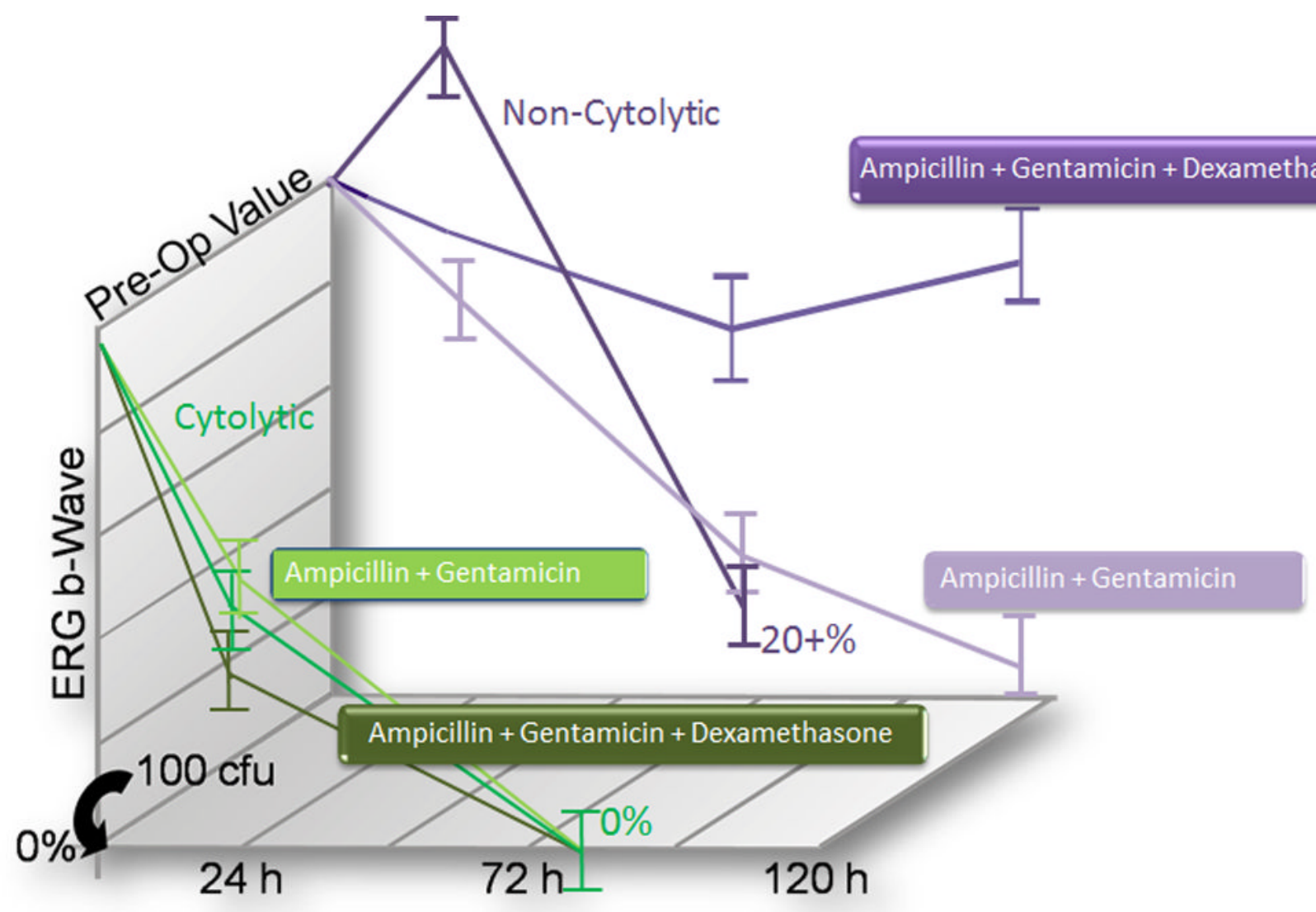

Figure 2.

Course of rabbit endophthalmitis as a function of treatment regimen, as measured by $\%$ ERG $\mathrm{B}$-wave amplitude retention (b-wave in infected eye/b-wave in control eye $\times 100$ ). Antibiotic therapy consisting of ampicillin $(1 \mathrm{mg} / 0.1 \mathrm{ml})$ and gentamicin $(200 \mathrm{ug} / 0.1 \mathrm{ml})$ for endophthalmitis from either cytolytic (in green) or non-cytolytic (in purple) E. faecalis provides little improvement over untreated controls. Inclusion of dexamethasone (400 ug/0.1 $\mathrm{ml}$ ) results in complete recovery of retinal function in eyes infected with non-cytolytic $E$. faecalis, but provides no measurable benefit for eyes infected with the cytolytic $E$. faecalis. 


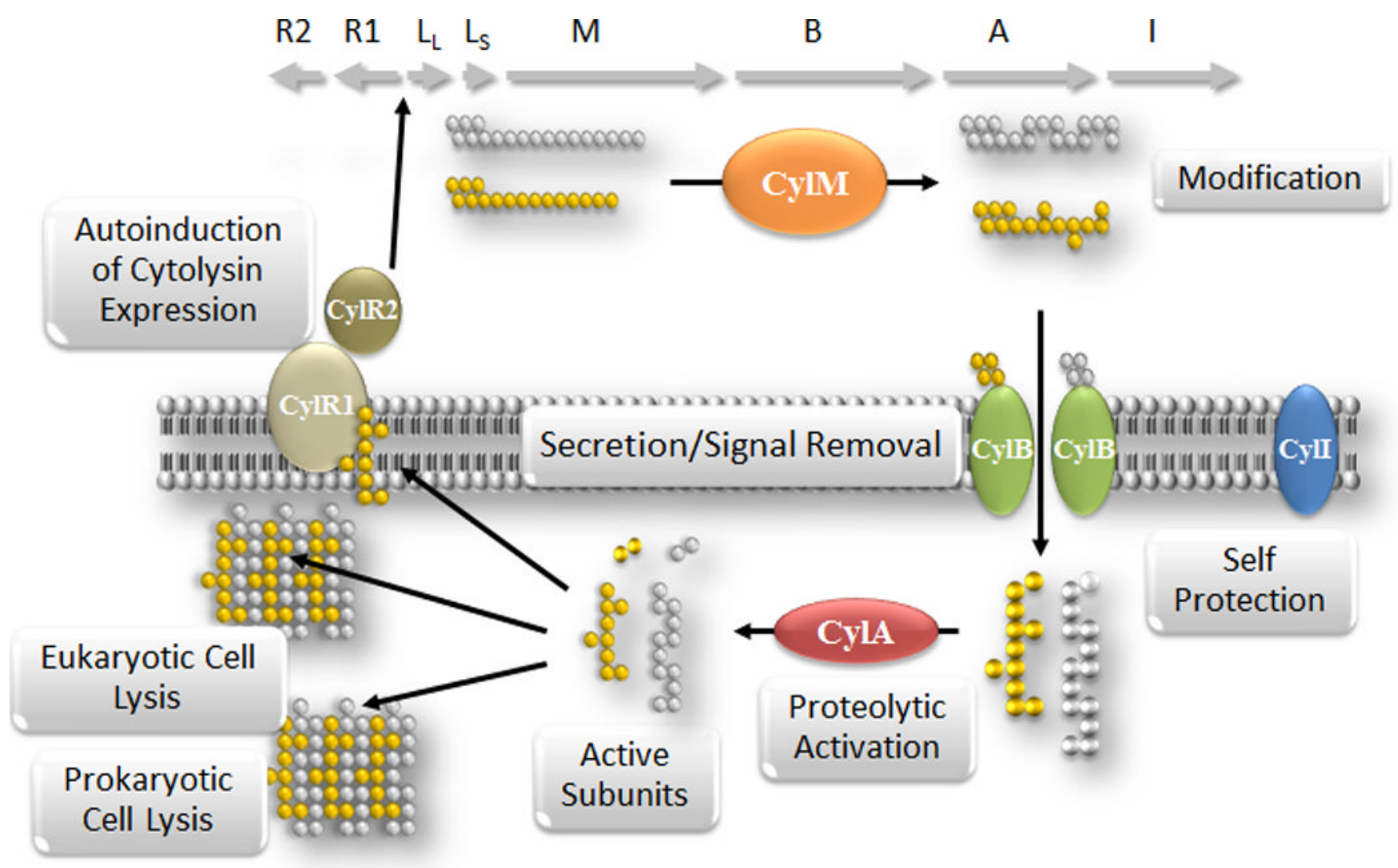

Figure 3.

The peptide subunits $\mathrm{CylL}_{\mathrm{L}}$ and $\mathrm{CylL}_{\mathrm{S}}$ are ribosomally synthesized in the cell. Following post-translational modification by CylM, they are cleaved and secreted to be activated extracellularly by CylA. This allows the fully active peptides to act together to lyse prokaryotic and eukaryotic cells, in addition to inducing expression of the cytolysin operon. CylR1 and CylR2 serve to repress expression of the operon. The cytolysin-producing cell itself is protected by CylI. 
Table 1

Prevalence of microorganisms in endophthalmitis

\begin{tabular}{|c|c|}
\hline Type of endophthalmitis & Common organisms \\
\hline \multicolumn{2}{|l|}{ Exogenous (83-98\%) } \\
\hline \multirow[t]{8}{*}{ Postoperative $^{a}$} & Bacteria \\
\hline & Gram positive ( $90 \%)$ \\
\hline & Coagulase-negative staphylococci $(70 \%)$ \\
\hline & Staphylococcus aureus (10\%) \\
\hline & Streptococcus species (9\%) \\
\hline & Enterococcus species (2\%) \\
\hline & Gram negative (4-6\%) \\
\hline & Fungi (3-21\%) \\
\hline \multirow[t]{5}{*}{ Post-traumatic $b$} & Staphylococcus species \\
\hline & Bacillus species \\
\hline & Streptococcus species \\
\hline & Gram- negative bacilli \\
\hline & Fungi \\
\hline \multirow[t]{2}{*}{ Post anti-VEGF injections ${ }^{c}$} & Coagulase-negative staphylococci \\
\hline & Viridans streptococci (e.g. Streptococcus mitis, Streptococcus salivarius) \\
\hline \multirow[t]{14}{*}{ Endogenous $^{d}(2-17 \%)$} & Bacteria \\
\hline & Gram positive \\
\hline & Streptococcus species \\
\hline & Staphylococcus aureus \\
\hline & Gram negative \\
\hline & Klebsiella \\
\hline & Escherichia coli \\
\hline & Pseudomonas \\
\hline & Neisseria meningitidis \\
\hline & Fungi \\
\hline & Candida species \\
\hline & Aspergillus \\
\hline & Cryptococcus \\
\hline & Fusarium \\
\hline
\end{tabular}

${ }^{a}$ In postoperative endophthalmitis, $90 \%$ of cases occur after cataract surgery

${ }^{b}$ Staphylococcus and Bacillus species are the most common causes of posttraumatic endophthalmitis with their incidence varying among studies

${ }^{c}$ Most reported cases do not list the causative organism so percentages were not included here

${ }^{d}$ Causative organisms of endogenous endophthalmitis vary widely with geographic location

Based on data from (EVS 1996, Anand et al. 2000, Chhabra et al. 2006, Diago et al. 2009, Klein et al. 2009, Leng et al. 2011, Nayak 2008, Smith et al. 2007)

Prog Retin Eye Res. Author manuscript; available in PMC 2013 July 01. 